\title{
Cradle-to-gate life cycle assessment of the production of separated mix of rare earth oxides based on Australian production route
}

\author{
Paul Koltun ${ }^{* \otimes}$, Vasyl Klymenko ${ }^{2 \bowtie}$ \\ ${ }^{1}$ Victoria University, Melbourne, VIC 3001, Australia \\ ${ }^{2}$ Central Ukrainian National Technical University, Kropyvnytskyi, 25006, Ukraine \\ *Corresponding author: e-mail Paul.Koltun@vu.edu.au, tel. +61408016244
}

\begin{abstract}
Purpose. Life cycle assessment (LCA) to investigate environmental impact resulting from the production of separated mixture of rare earth oxides (REO) mined in Australia.

Methods. Analytical study of the literature reviews data, measurements and manufacturers' reports, life cycle inventory databases and reasonable estimates of the processes involved in the production of a separated mixture of different REO was performed. To refine the data, was used an approach based on the basis of the matrix and Monte Carlo simulation. To estimate environmental impact from the production of each REO, the method of distributing the environmental impact between different REO was also used.

Findings. The obtained results show that the production process of separated REO has a different environmental impact depending upon type of REO: for light REO global warming potential (GWP) is 1.7-3.9 t of $\mathrm{CO}_{2}$ eq./t of produced REO; a substantially higher impact for medium and heavy REO (GWP is about $90 \mathrm{t}$ of $\mathrm{CO}_{2}$ eq. per tonne of REO). The major impact comes from production of praseodymium/neodymium ( $\mathrm{Pr} / \mathrm{Nd}$ ) oxides (it's about $80 \%$ for GWP). The environmental impact from the radioactivity exposure (if waste from the production process is properly managed) shows a relatively low contribution to overall impact on human health (about $0.2 \%$ ).

Originality. The paper pioneered the method of environmental impact distribution, developed by the authors considering the economic value associated with the removal of several co-products from the production processes. The Monte Carlo simulation was used to determine uncertainty of the obtained results during the LCA study. Such approach was allowed more accurately assess different components of the environmental impact resulting from REO production in Australia for the technology described in this paper.

Practical implications. The results obtained in the study on the basis of the proposed methodology allows to identify environmental "hot spots" in the production of separated REO and take practical steps to reduce the negative environmental impact of such production.
\end{abstract}

Keywords: rare earth elements, life cycle assessment, environmental impacts, Monte Carlo simulation

\section{Introduction}

\subsection{Rare earth metals and their uses}

The term "rare earth" (RE) is applied to the group of seventeen, chemically very similar, elements with fifteen elements of lanthanide series (atomic numbers from 57 to 71), as well as, scandium (atomic number 21) and yttrium (atomic number 39). The last two elements are technically defined as RE by the International Union of Pure and Applied Chemistry. The lanthanide series is classified into three broad groups of elements as presented in Table 1.

The last column of Table 1 presents volatility of the prices within the year 2013 relative to the prices presented in the previous column.

REEs were initially described as rare because they were originally obtained from relatively rare minerals. In fact
REEs are not rare and generally found together (with the exception of promethium) in varying concentrations (usually very low) in a number of ores (more than 200). The unique atomic structure of REE gives them their unique properties and subsequently a wide variety of advanced technology applications. In most applications, REEs are used based on their technical superiority imparted by specific properties of a particular element. The current applications of REEs are summarised in Table 2.

Widely utilisation of REE by industry, specifically in "green industry", such as renewable energy, light emitted diodes (LED), etc. and REE classification as "critical materials" [1] brought attention of life cycle assessment (LCA) community and increased number of publications related to LCA of the production of RE and RE based products (for example [2]-[6]). 
Table 1. Rare earth elements (REE), their oxides, weights and prices (Prices for REO are taken from [7], [8])

\begin{tabular}{|c|c|c|c|c|c|c|}
\hline Rare earth type & $\begin{array}{l}\text { Element } \\
\text { (symbol) }\end{array}$ & $\begin{array}{l}\text { Atomic weight/ } \\
\text { density, }\left(\mathrm{g} / \mathrm{cm}^{3}\right)\end{array}$ & Oxide & $\begin{array}{c}\text { Oxide mol. } \\
\text { weight }\end{array}$ & $\begin{array}{c}\text { Price on } 2012 / 2013 \\
(\mathrm{US} \$ / \mathrm{kg})\end{array}$ & $\begin{array}{l}\text { Volatile } \\
(\% \text { change })\end{array}$ \\
\hline \multirow{5}{*}{ Light } & Lanthanum (La) & $139 / 6.146$ & $\mathrm{La}_{2} \mathrm{O}_{3}$ & 326 & 13 & -20.0 \\
\hline & Cerium $(\mathrm{Ce})$ & $140 / 6.670$ & $\mathrm{CeO}_{2}$ & 172 & 12 & -16.7 \\
\hline & Praseodymium (Pr) & $141 / 6.673$ & Pr6O11 & 1024 & 175 & 0.0 \\
\hline & Neodymium (Nd) & $144 / 7.008$ & $\mathrm{Nd}_{2} \mathrm{O}_{3}$ & 336 & 94 & -7.4 \\
\hline & Promethium $(\mathrm{Pm})^{*}$ & $147 / 7.264$ & - & - & - & - \\
\hline \multirow{3}{*}{ Medium } & Samarium (Sm) & $150 / 7.520$ & $\mathrm{Sa}_{2} \mathrm{O}_{3}$ & 348 & 30 & -33.0 \\
\hline & Europium (Eu) & $152 / 5.544$ & $\mathrm{Eu}_{2} \mathrm{O}_{3}$ & 352 & 2320 & -38.2 \\
\hline & Gadolinium (Gd) & $157 / 7.901$ & $\mathrm{Gd}_{2} \mathrm{O}_{3}$ & 362 & 95 & 0.0 \\
\hline \multirow{7}{*}{ Heavy } & Terbium $(\mathrm{Tb})$ & $159 / 8.230$ & $\mathrm{~Tb}_{4} \mathrm{O}_{7}$ & 748 & 1900 & -57.4 \\
\hline & Dysprosium (Dy) & $162 / 8.5511$ & $\mathrm{Dy}_{2} \mathrm{O}_{3}$ & 373 & 750 & -37.3 \\
\hline & Holmium (Ho) & $165 / 8.795$ & $\mathrm{Ho}_{2} \mathrm{O}_{3}$ & 378 & 300 & +177.0 \\
\hline & Erbium (Er) & $167 / 9.066$ & $\mathrm{Er}_{2} \mathrm{O}_{3}$ & 382 & 225 & -26.7 \\
\hline & Thulium (Tm) & $169 / 9.321$ & & & & \\
\hline & Ytterbium (Yb) & $173 / 6.966$ & $\mathrm{Yb}_{2} \mathrm{O}_{3}$ & 394 & 235 & -15.0 \\
\hline & Lutetium $(\mathrm{Lu})$ & $175 / 9.841$ & $\mathrm{Lu}_{2} \mathrm{O}_{3}$ & 398 & 2135 & -35.0 \\
\hline \multirow{2}{*}{ Similar to RE } & Scandium $(\mathrm{Sc})$ & $45 / 2.989$ & $\mathrm{Sc}_{2} \mathrm{O}_{3}$ & & 15500 & +16.1 \\
\hline & Yttrium $(\mathrm{Yt})$ & $89 / 4.469$ & $\mathrm{Yt}_{2} \mathrm{O}_{3}$ & 226 & 75 & +2.7 \\
\hline \multirow{3}{*}{ Mix of light REE } & $\begin{array}{c}\text { Didymium } \\
(85 \% \mathrm{Nd}+15 \% \text { Pr })\end{array}$ & $-/ 6.958$ & - & $\sim 440$ & $\sim 60$ & \\
\hline & $\begin{array}{c}\text { Mischmetal } 1 \\
(25 \% \mathrm{La})\end{array}$ & - & - & $\sim 220$ & $\sim 12$ & \\
\hline & $\begin{array}{c}\text { Mischmetal } 2 \\
(48 \% \mathrm{Ce})\end{array}$ & - & - & $\sim 260$ & $\sim 10$ & \\
\hline
\end{tabular}

Table 2. Applications of rare earth elements (REEs)

\begin{tabular}{|c|c|c|c|}
\hline Industry & Technical application & Product & Rare earth used \\
\hline Optics & $\begin{array}{l}\text { Phosphors } \\
\text { High-refractive glass } \\
\text { Lasers }\end{array}$ & $\begin{array}{c}\text { Colour televisions } \\
\text { Fluorescent lamps, LEDs } \\
\text { X-ray screens } \\
\text { Video camera lens } \\
\text { Photocopiers } \\
\text { Medical technology }\end{array}$ & $\begin{array}{l}\text { Europium, } \\
\text { Yttrium, and } \\
\text { Terbium } \\
\\
\text { Lanthanum } \\
\text { Gadolinium }\end{array}$ \\
\hline Magnetics & Permanent magnets & $\begin{array}{c}\text { Headphones } \\
\text { Loudspeakers } \\
\text { Computer disc drives } \\
\text { Video recorders } \\
\text { Electric motors } \\
\end{array}$ & $\begin{array}{l}\text { Neodymium, Samarium, } \\
\text { and Dysprosium }\end{array}$ \\
\hline Electronics & $\begin{array}{c}\text { Capacitors } \\
\text { Memory systems } \\
\text { Magneto-optical recording }\end{array}$ & $\begin{array}{c}\text { Computers } \\
\text { Computers } \\
\text { Data storage } \\
\end{array}$ & $\begin{array}{c}\text { Medium and } \\
\text { heavy rare earth }\end{array}$ \\
\hline Ceramics & $\begin{array}{l}\text { Oxygen sensors } \\
\text { Hard-wearing, temperature- } \\
\text { resistant materials } \\
\text { High temperature conductivity }\end{array}$ & $\begin{array}{c}\text { Auto emissions control } \\
\text { Engine valve parts } \\
\text { Piston linings } \\
\text { Machine tool cutting edges } \\
\text { Computers }\end{array}$ & Heavy rare earth \\
\hline Metallurgy & $\begin{array}{c}\text { Pyrophoric properties } \\
\text { Alloys }\end{array}$ & $\begin{array}{c}\text { Flints } \\
\text { Aircraft parts }\end{array}$ & Light rare earth \\
\hline Catalysis & $\begin{array}{l}\text { Oil refining catalysis } \\
\text { Catalytic converters }\end{array}$ & $\begin{array}{c}\text { Petrol } \\
\text { Emission control systems }\end{array}$ & Light rare earth \\
\hline
\end{tabular}

Researches, mostly, took into consideration only Chinese root of the REE production, as China currently producing more than $95 \%$ of the world total supply [9]. Although there are many proven reserves of REE in the world, however, due to different reasons and not least of the environmental impact till recent time China dominated production of REE. Growing demand for REE and some export restrictions imposed by China are negatively affected REE consumers in USA, Europe and Japan [1]. To reduce negative effect of such situa- tion some companies in countries like USA, Russia, Australia began to investigate possibilities and some even already began of mining and production of separated RE oxides and metals. Thus it would be interesting to assess environmental impacts of their roots of production and compare them with REE produced in China at least for the major environmental impacts. This paper studies the LCA of Australian root of the production of separated RE oxides taking into consideration most important for Australia environmental factors. 


\section{Methodology}

\subsection{Goal}

Primary goal of the study was to assess the environmental impact of the production route of REO mind and preprocessed in Australia and then separated by Lynas Advanced Material Plant (LAMP) in Malaysia using "cradle-togate" LCA. The conducted study is descriptive, rather than decision-making oriented [10]. Another goal of the study was to identify hot-spots of REO production with the aim of reducing environmental impact from REO production. An additional goal was to compare the results with already published results for RE production by China.

\subsection{LCA scope and functional unit}

The scope of the study included infrastructure, mine development and REO mining, production of REO concentrate in Australia and the final processing of REO concentrate to produce separated mix of REO in Malaysia. The purpose was to include every critical link in the process of production of individual REO, including background and auxiliary processes, with the exception of administrative, information and other supportive services. The choice to include all operations described below was based on modelling of production of separated REO mix from mined ore through to production of separated oxides and carbonates of REE. The scope was consistent with a "cradle-to-gate" LCA (downstream life cycle of REO was not included.), and it extended further upstream to encompass pre-mining activity of the company. Unlike REO produced by China where RE mines been established for a long time this stage of REO production from Australia can have substantial contribution to the environmental impact from overall REO production. The scope of the study also included both direct and indirect materials and chemicals input, energy and water consumption, as well as waste generation due to production separated REO.

The inventory was based mostly on reports and presentation produced by Kinhill Engineers Pty. Ltd [11] and Lynas Pty. Ltd [7], [12] regarding current and future routes of production of separated REO from Mt. Weld deposit (WA). Whenever these sources of data were not sufficient for LCI to account for all the inputs to the processes, the left over inputs had been modelled using different sources of publicly available data including well known commercial LCA software SimaPro 7.3 [13]. The latter sources accounted for all known inputs to the processes under consideration, as well as emissions and wastes and were basically sufficient for characterisation of different environmental impacts. Taking into account the diverse sources of the inventory data, an uncertainty analysis was performed using approach based on pedigree matrix [14] and Monte-Carlo simulation from SimaPro 7.3 software.

The study life cycle impact assessment (LCIA) method was based on characterisation factors taken from two methods:

1) some characterisation factors are taken from Ecoindicator 99 [13]: carcinogens and human health;

2) some are taken from Eco-indicator 95 (Australian adjustment) [13]: GWP, cumulative primary energy demand, water use, solid waste generation.

The chosen set of factors consisted of mix of resource factors (water use), damage category factors or endpoint level in ISO terminology [15] (human health) and midpoint factors (rest of the factors). Such choice reflects the most important for Australia potential environmental impact due to the production of separated mix of REO.

The functional unit for the study (that is unit of endproduct to be considered) was defined as 1 tonne of separated mix of REO produced by LAMP in Malaysia. As the current technology produces REO only in combination (one of the major problem of REO producers is difference between REO demand and their natural occurrences, which corresponds to the lower market price for lower demanded REO), thus the environmental impacts of REO production was shared between all produced REO (similarly to cost of production). The allocation of environmental impacts from combined REO production in this study was based on their economic value, composition of REO in the final mix of production and atomic mass of produced rare earth elements [2].

\subsection{Major assumptions}

An LCI was grouped into three types of processes:

1) ore mining;

2) ore beneficiation;

3) REO extraction and separation.

Data used in production activities were grouped accordingly. Water, which was also included in the inventory was recycled water (from mine dewatering and water supply). Water released from the processes was also included in the inventory, as it was considered to be contaminated and produced adversarial environmental impacts.

Both raw materials inputs and core capital goods were included in the inventory. Core capital goods are defined as installations and heavy equipment critical to processes of REO production. These included heavy vehicles, reaction tanks, primary pipes, and large storage tanks. Auxiliary equipment such as connector pipes, structural skeletons, monitoring equipment were not included. Elements of nonprocess mine infrastructure included in the inventory were roads, steel buildings, water supply and electricity generators. Equipment used in administration and maintenance such as small trucks, computers, protective clothing, was omitted. The omission of small auxiliary was justified by undertaken sensitivity analysis.

Employee support services such as food, medical, and housing services were not included due to insufficient data.

An assumption was made that the rare earth deposit at Mt. Weld (Australia) was mined at a rate of 110000-220000 tonnes per annum (t/a) of ore (based on production 11000-22000 t/a separated REO oxides) The mining used conventional open-cut mining method. The mined ore delivered to the beneficiation plant at nearby site, which produced 220000-45000 t/a dry (27500-56000 t/a wet) concentrate [7]. The electrical energy required for ore mining and beneficiation was generated on site by electrical generators using LPG [11]. The chemicals required for beneficiation and fuel were transported by road from Perth. The produced REO concentrate was transported by road to Fremantle port and then transported by ships to LAMP for the production of separated REO (light and medium). The major components of production route are outlined in Figure 1.

The production route of REO from Mt. Weld deposit has been studied for the past two decades. The key elements of the study included pilot plant trials at the Lakefield Research Laboratories in Ontario, Canada. 


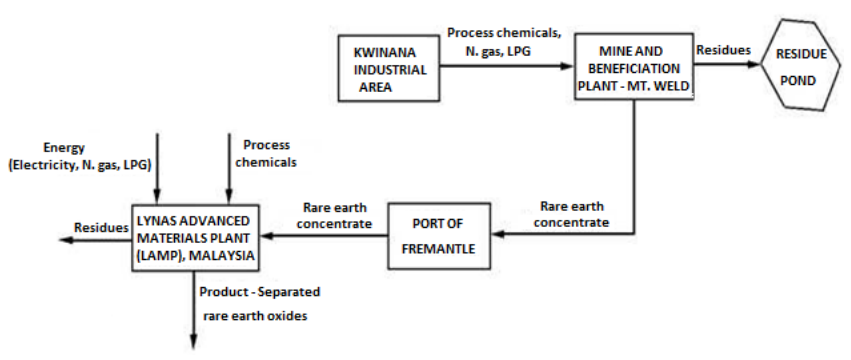

Figure 1. Overview of REO production by Australian route by based on [11], [16]

And Australian Mineral Development Laboratories (AMDEL) in Adelaide, hydrometallurgical benchmark test works (including radiological studies) at Australian Nuclear Science and Technology Organisation (ANSTO) laboratories at Lucas Heights, NSW [11]. The assessment of the best place for the processing concentrate produced by Mt. Weld beneficiation plant has also been done. Details of the project as a part of environmental and social impacts were referred to Western Australia Environmental protection Agency (WA EPA). For the purpose of this study, the production of separated REO was divided into eight major stages:

- major infrastructure development for ore mining and beneficiation at Mt. Weld;

- mine development;

- ore mining;

- beneficiation of ore at Mt. Weld to form an ore concentrate (5 stages);

- transport the ore concentrate to by road to Fremantle port, then by ship to Malaysia, then by road to a secondary process plant (LAMP);

- process of the ore concentrate to produce separated REO (10 stages);

- effluent treatment (2 stages;

- transport of RE products to port in Malaysia for export.

Location of Mt. Weld deposit and beneficiation plant and proposed transport routes for shipment REO concentrate to LAMP are shown in Figure 2.

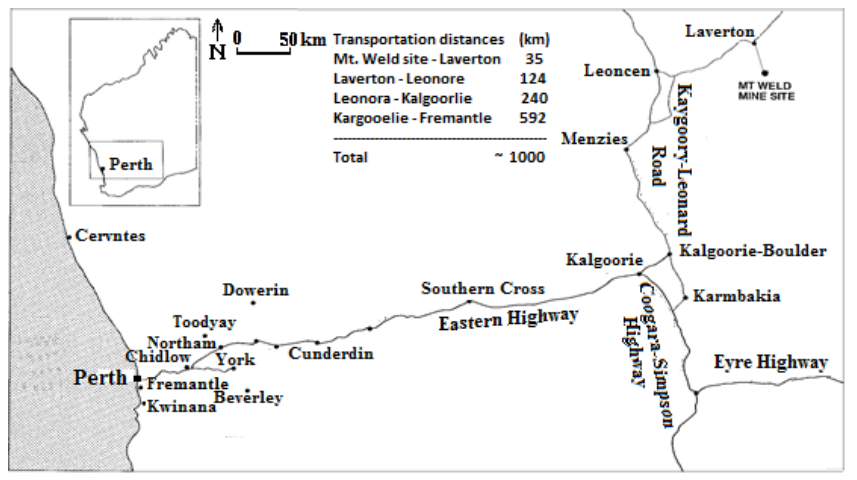

Figure 2. Location of Mt. Weld rare earth deposit [17]

\subsection{Data collection and management}

The REO production process model was based on written and graphic descriptions in corporate literature and from different published sources. Primary publicly available data were used as the information source whenever possible. When primary data was missing, inputs were calculated based on stoichiometric formulas (for chemical reactions), equations in reference books, or using, when necessary, generic industry data. Areas and distances utilized in transportation were estimated from satellite imagery in Google Earth software [17].

The inventory data was managed in SimaPro 7.3 [13] software. Original processes and product stages were created for the primary unit processes, as well as, for direct and indirect inputs to those processes. Data underlying background processes were taken from SimaPro 7.3. Some of these data have been altered, such as in the case of electricity produced by generator or electricity from Malaysian grid [18].

Inventory cut-offs were not used. In many cases items with less than $1 \%$ of contribution to impact were included. Many of these inputs were left in the inventory both to demonstrate their lack of significance and to make the inventory more complete for use with other measures of impact, for which relative impact would vary.

\section{Ore mining}

\subsection{Infrastructure}

Before a deposit can be mined the necessary infrastructure such as roads, electricity and water supply, and office facilities need to be in place. For this reason, infrastructure establishments were included into inventory. Inputs to mine infrastructure based on data from [19] and RE deposit (presented in section 2.3) are shown in Table 3. The last column in Table 3 represents variances of lognormal distribution functions associated with figures for infrastructure allocation per tonne of produced REO.

Table 3. Inputs to process Mt. Weld mine infrastructure per $1 \mathrm{t}$ of separated mix of REO production

\begin{tabular}{lcccc}
\hline \multicolumn{1}{c}{ Process } & Amount & Unit & $\begin{array}{c}\text { Per 1 tonne } \\
\text { of mix REO }\end{array}$ & $\sigma^{2}$ logn \\
\hline $\begin{array}{l}\text { Hauling Road } \\
\begin{array}{l}\text { Service Road, } \\
\text { Laverton - Mt. Weld }\end{array}\end{array}$ & 5 & $\mathrm{~km}$ & $4.11 \mathrm{E}-06$ & 1.5 \\
$\begin{array}{l}\text { Buildings, pump } \\
\text { station, steel }\end{array}$ & 600 & $\mathrm{k}$ & $4.04 \mathrm{E}-6$ & 1.2 \\
$\begin{array}{l}\text { Water supply } \\
\text { network (water pipes) }\end{array}$ & 10 & $\mathrm{~km}$ & $8.24 \mathrm{E}-06$ & 1.2 \\
$\begin{array}{l}\text { Basin construction } \\
\text { (residue ponds) }\end{array}$ & 40 & $\mathrm{ha}$ & $3.28 \mathrm{E}-05$ & 1.2 \\
$\begin{array}{l}\text { Borders construction } \\
\begin{array}{l}\text { Clearing biomass } \\
\text { before mining }\end{array}\end{array}$ & 10 & $\mathrm{~km}$ & $9.86 \mathrm{E}-06$ & 1.3 \\
\hline
\end{tabular}

Land use prior to mining was predominately bush land [11]. Loss of aboveground biomass due to clearing for mining was included. Mine roads, water and buildings were included in the inventory. Total length and width of mine roads was estimated using satellite imagery [17]. Models for road materials and constructions were created for three roads types:

1) hauling roads for use by heavy mine vehicles (approx. $25 \mathrm{~m}$ in width);

2) service roads (approx. $10 \mathrm{~m}$ in width);

3) a provincial highway.

Road models were based on standards in accordance for support of vehicle weight and material type, based on California Bearing Ratios [20]. Materials and fuel use for the mine heavy machines were based on the "Road/CH/I U" model in Ecoinvent [21]. Total mine building area is 60 ha (data obtained from [11]). Water supply and a pump station 
were also based on Ecoinvent "Pumpstation" [13] and "Water supply network" processes [22]. Distance for water supply networks were assumed equal to the major mine road length (hauling road) and distance to Granny Smith Gold Mine (GSGM), and total water required for dewatering the mine site was reported by [11].

The infrastructure development includes construction of residue ponds (Fig. 3). The entire pond area is cleared and top soil is removed and stored for use of site rehabilitation. The pond is constructed in zones and residue will be deposited in series of linked ponds.

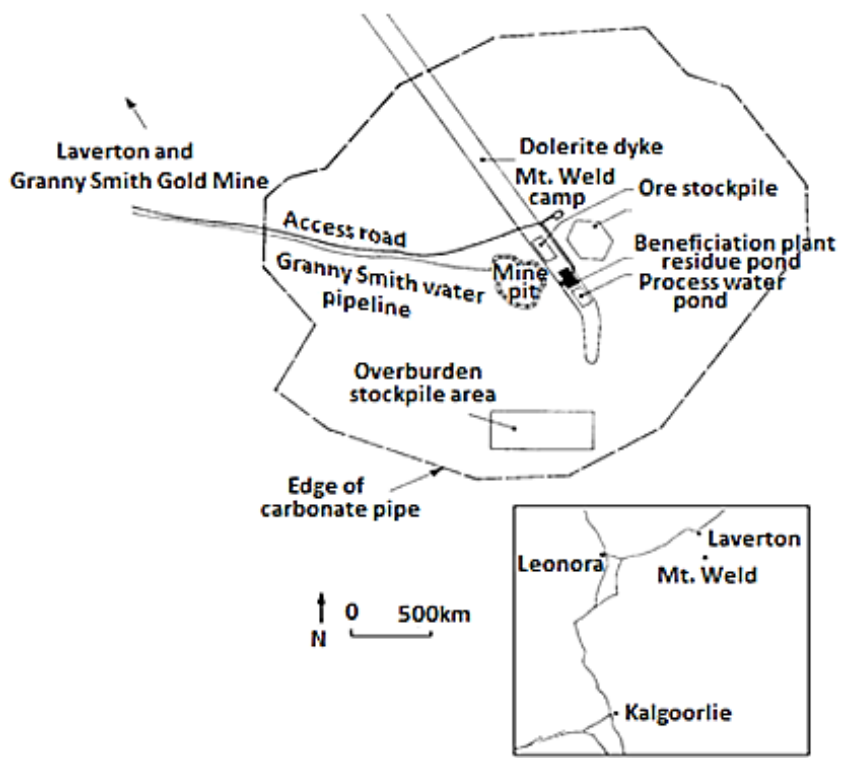

Figure 3. Conceptual layout of facilities at Mt. Weld [11]

Each pond is approximately $75 \times 75 \mathrm{~m}$ and will be held during about two years for the production of residues (based on the estimated production of $27500 \mathrm{t} / \mathrm{a}$ wet concentrate contains $80 \%$ of solids). Ponds are clustered in groups of three - five clusters would be required to contain residues from 30 years of production. Each pond is excavated to an average of $5 \mathrm{~m}$ deep and lined with a compacted clay base of $0.3 \mathrm{~m}$ thick. The maximum depth of residue allowed to be placed in ponds is $2.5 \mathrm{~m}$ allowing $2.2 \mathrm{~m}$ for "freeboard".

Decommissioning stage was also included within infrastructure development, where an average of $1.5 \mathrm{~m}$ of soil cover and $0.5 \mathrm{~m}$ of quarried rock would be placed on the dried residue surface to provide long term protection from wind and water erosion. The surface of decommissioning pond would be rehabilitated using top soil stored from pond construction. Approximately $0.5 \mathrm{~m}$ of top soil would be added giving a final soil cover depth of $2.5 \mathrm{~m}$.

Inputs required for the development of residue ponds and decommissioning stage are presented in Table 3.

\subsection{Mine development}

13000-14000 ML of water was pumped from the bore field. 8.500-9000 ML of this volume was supplied for the use of GSGM, approximately $4 \mathrm{ML}$ per day (ML/d), the rest will be stored (evaporate/infiltrate) in the area of 40 ha (this area is also designated for overburden and beneficiation plant's residue pond [11]. The area was cleared and the top soil was stockpiled prior to release of water for future rehabilitation of the site. The mine-pit area is approximately
$300 \times 250 \mathrm{~m}$ for 10 years of ore mining. The overburden consisted of $20 \mathrm{~m}$ of deep alluvium sediment, which was removed by excavators and trucks. The top $30 \mathrm{~mm}$ of overburden together with vegetation was stockpiled for rehabilitation purpose. The $1.5 \mathrm{Mm}^{3}$ of overburden was used for construction purposes. The remaining overburden covered 17 ha and (10 $\mathrm{m}$ high) and was constructed to reduce erosion and would be used for rehabilitation [11]. Water allocation from the mining site is presented in Table 4.

Table 4. Allocation of water from initial mine dewatering

\begin{tabular}{lc}
\hline \multicolumn{1}{c}{ Location } & Volume (ML) \\
\hline Granny Smith Gold Mine & 9000 \\
Unused pit (storage) & 2160 \\
Mt. Weld (construction site) & 600 \\
Mt. Weld storage/evaporation/infiltration basin & 2240 \\
Total & 14000 \\
\hline
\end{tabular}

The mining preparation phase commenced with the removal and storage of topsoil. Drill rigs were used to drill bore holes for placement of ANFO explosives for loosening overburden. Explosives were assumed to be ANFO type [23]. Large mining machines scraped overburden and ore into $50 \mathrm{t}$ off-road trucks. Overburden was transferred into overburden stockpile areas. The total amounts of overburden, explosives, heavy mining machines and trucks used and water pumped out of mining site modeled for establishing open-cut mines based on data reported [11] and Ecoinvent [22] and presented in Table 5. According the Ecoinvent report [24] there was no relevant waste produced in this phase. The overburden would be used in mine rehabilitation and thus was not treated as waste. The only relevant direct emissions from mine preparation were the dust emissions to air.

Table 5. Inputs to process mine preparation and construction per 1 t of separated mix of REO production

\begin{tabular}{lcccc}
\hline \multicolumn{1}{c}{ Process } & Amount & Unit & $\begin{array}{c}\text { Per 1 tonne } \\
\text { of mix REO }\end{array}$ & $\sigma^{2}$ logn \\
\hline $\begin{array}{l}\text { Explosives (ANFO), } \\
\text { at Mt. Weld }\end{array}$ & $7.53 \mathrm{E}+02$ & tonne & $6.17 \mathrm{E}-04$ & 1.5 \\
$\begin{array}{l}\text { Overburden removal } \\
\text { Hydraulic excavators, }\end{array}$ & $1.58 \mathrm{E}+07$ & tonne & $1.29 \mathrm{E}+01$ & 1.2 \\
$\begin{array}{l}\text { bulldozers, loaders } \\
\text { Trucks (50 t off-road), }\end{array}$ & $1.3 \mathrm{E}+02$ & $\mathrm{hr}$ & $1.89 \mathrm{E}-04$ & 1.3 \\
$\begin{array}{l}\text { at Mt. Weld } \\
\begin{array}{l}\text { Diesel, at Mt. Weld } \\
\text { Pumping water }\end{array}\end{array}$ & $2.94 \mathrm{E}+06$ & $\mathrm{~kg}$ & $9.04 \mathrm{E}-03$ & 1.5 \\
$\begin{array}{l}\text { to storage basin } \\
\begin{array}{l}\text { Pumping water } \\
\text { to GSGM }\end{array}\end{array}$ & $5.02 \mathrm{E}+06$ & $\mathrm{~kL}$ & $4.11 \mathrm{E}+00$ & 1.1 \\
$\begin{array}{l}\text { LPG (for electricity } \\
\text { generator) }\end{array}$ & $3.26 \mathrm{E}+05$ & $\mathrm{~kg}$ & $2.67 \mathrm{E}-01$ & 1.5 \\
\hline
\end{tabular}

\subsection{Mining operations}

Mining ore in open pit mine is an established technology, which is widely used, not only for REO mining. This technology is not expected to change significantly in the following decade.

The REO ore was mined at 110000-220000 t/a and it was carried out for a single period of 1025 weeks with conventional open-cut mining method using bulldozers, hydraulic excavators, 50 tonnes off- highway trucks, loaders. The ore was transferred to beneficiation plant situated $1.5 \mathrm{~km}$ away from the Mt. Weld mine by trucks and was stockpiled there (maximum capacity $60000 \mathrm{~m}^{3}$ ). The stockpiled ore was 
spayed regularly to maintain the excavated moisture content of the ore. The excess water runoff was directed to storm water disposed system. The run-of mine (ROM) was a uniform, fine-grained sediment of ore with a pit moisture content of $8 \%$. Excess overburden from beneficiation plant was trucked back to Mt. Weld site and was stockpiled there located away from mine ore deposit. Concentration of major radionuclides associated with monazite mined in Mt. Weld are: thorium and uranium $0.02 \%$ (approximately 50 times less than in monazite mined in beach sand) [11]. The place of facilities at Wt. Weld site is shown in Figure 3.

The extraction phase model is based on a process descriptions reported by [11]. A total of $14.9 \mathrm{Mt}$ of ore at average grade $9.8 \%$ of REO (1.46 Mt) was mined from open cut mine established in the Central Lanthanide District (LCD) at Mt. Weld (WA). As in the previous stage, large mining machines hydraulic excavators, bulldozers, loaders were used to scrape ore into $50 \mathrm{t}$ off-road trucks. Small amount of explosives were occasionally used. The total amount of heavy mining machines and trucks used, together with fuel used, were modelled using the Ecoinvent data presented in SimaPro 7.3 [13] (Table 6).

Table 6. Inputs to process $R E O$ ore mining per $1 t$ of separated mix of REO production

\begin{tabular}{lrccc}
\hline \multicolumn{1}{c}{ Process } & Amount & Unit & $\begin{array}{c}\text { Per 1 tonne } \\
\text { of mix REO }\end{array}$ & $\sigma^{2} \operatorname{logn}$ \\
\hline $\begin{array}{l}\text { Ore mined } \\
\text { Hydraulic excavators, }\end{array}$ & $1.49 \mathrm{E}+07$ & $\mathrm{t}$ & $1.22 \mathrm{E}+01$ & 1.1 \\
bulldozers & $1.5 \mathrm{E}+04$ & $\mathrm{hr}$ & $1.22 \mathrm{E}-02$ & 1.3 \\
$\begin{array}{l}\text { Loaders, at Mt. Weld } \\
\text { Trucks (50 t off-road), }\end{array}$ & $1.5 \mathrm{E}+04$ & $\mathrm{hr}$ & $1.22 \mathrm{E}-02$ & 1.3 \\
$\begin{array}{l}\text { at Mt. Weld } \\
\begin{array}{l}\text { Diesel, at Mt. Weld } \\
\text { LPG (for electricity }\end{array}\end{array}$ & $1.34 \mathrm{E}+07$ & $\mathrm{~kg}$ & $1.10 \mathrm{E}+01$ & 1.5 \\
generator) & $7.38 \mathrm{E}+06$ & $\mathrm{~kg}$ & $6.04 \mathrm{E}+00$ & 1.5 \\
\hline
\end{tabular}

\section{Beneficiation processes}

\subsection{Ore beneficiation}

110000 t/a RE ore was beneficiated to produce 22000 t/a dry (27500 t/a wet) REO concentrate (this amount of ore has to be processed for the $1^{\text {st }}$ stage of production [16].

The beneficiation plant worked 300 days per annum with two shutdown periods. The flotation process was conducted continuously during working periods and produces 3.0-4.0 tonne per hour $(\mathrm{t} / \mathrm{h})$ REO concentrate. The phosphate flotation process was adopted for the beneficiation plant, involving: feed preparation of the ore, froth flotation and filtration of residues (slurry with comparatively low solid content). The residues were pumped to residue pond where supernatant water was reclaimed and recycled for the beneficiation plant. The residues from beneficiation plant were discharged with a solid content about $8 \%$ at the rate approximately $140 \mathrm{~m}^{3} / \mathrm{h}$ and $40 \mathrm{~kL}$ of water from the that liquor are recycled. Wash-down water was collected, combined with beneficiation residues.

All beneficiation processes were carried out within enclosed buildings which included: office building, laboratory, workshop, reagent and consumable store building and load-out facility for the final concentrate. In addition there were process water storage pond, fuel storage and water treatment facilities. Some buildings and facilities are shown in Figure 3.
Feed preparation. Feed preparation circuit reduced runof-mine (ROM) ore to the 100 microns particles by scrubbing, attrition andgrinding. Sodium silicate $\left(\mathrm{Na}_{2} \mathrm{SiO}_{3}\right)$ was added to the scrubber to facilitate the dispersion of fine particles.

Lime removal. This process followed the feed preparation and consisted of three stages. The sodium carbonate $\left(\mathrm{Na}_{2} \mathrm{CO}_{3}\right)$ known also as soda ash was added to water to reduce water hardness and acted as a $\mathrm{pH}$ modifier. The overflow from each stage of the process was discharged into residue pond.

The liquor which contains approximately $40 \%$ of solids was used as flotation feed. The flotation itself required additional demineralised water and reagents. The product of flotation process required four stages of cleaning and conditioning. The conditioning reagents added to each stage are:

1) sodium sulphate $\left(\mathrm{Na}_{2} \mathrm{~S}\right)$ - acted as depressant and $\mathrm{pH}$ modifier;

2) WWQ - high quality wheat starch was used as depressant for silicate and iron bearing gangue;

3) DA663 - an acrylic polymer, acted as additional depressant for iron;

4) CB110 - a blended type of collector containing fatty acid derivative added for better flotation of RE minerals.

The final product of the flotation process contained about $50 \%$ of REO (dry weight). This product was filtered to reduce water content to $10-15 \%$ and then stored. This concentrate paste was stored on site in a $500 \mathrm{~m}^{3}$ tank (surrounded by earth wall) to be transported to the LAMP.

The major inputs for beneficiation process modelled basing on data reported by [11] for the final production of 1 tone of separated mix of REO are presented in Table 7.

Table 7. Inputs for REO concentrate making at the beneficiation plant at Mt. Weld per $1 \mathrm{t}$ of separated mix of REO production

\begin{tabular}{|c|c|c|c|c|}
\hline Stage & Reagent & Units & $\begin{array}{l}\text { Per } 1 \mathrm{t} \text { of } \\
\text { REO }\end{array}$ & $\sigma^{2} \log n$ \\
\hline Feed Preparation & $\begin{array}{c}\text { Sodium Silicate } \\
\left(\mathrm{Na}_{2} \mathrm{SiO}_{3}\right)\end{array}$ & $\mathrm{kg}$ & $1.02 \mathrm{E}+01$ & 1.2 \\
\hline \multirow{2}{*}{ Lime removal } & $\begin{array}{c}\text { Sodium Carbonate } \\
\left(\mathrm{Na}_{2} \mathrm{CO}_{3}\right)\end{array}$ & $\mathrm{kg}$ & $2.55 \mathrm{E}+00$ & 1.2 \\
\hline & $\begin{array}{l}\text { Water (recycled } \\
\text { from pond) }\end{array}$ & $\mathrm{kL}$ & $1.91 \mathrm{E}+01$ & 1.7 \\
\hline \multirow{5}{*}{$\begin{array}{l}\text { Froth flotation } \\
\text { (4 stages) }\end{array}$} & $\begin{array}{l}\text { Sodium Sulphate } \\
\qquad\left(\mathrm{Na}_{2} \mathrm{~S}\right)\end{array}$ & $\mathrm{kg}$ & $7.65 \mathrm{E}+01$ & 1.2 \\
\hline & $\begin{array}{l}\text { Depressant } \\
\text { (WWQ) }\end{array}$ & $\mathrm{kg}$ & $2.55 \mathrm{E}+01$ & 1.2 \\
\hline & $\begin{array}{l}\text { Depressant } \\
\text { (DA663) }\end{array}$ & $\mathrm{kg}$ & $5.10 \mathrm{E}+00$ & 1.2 \\
\hline & $\begin{array}{l}\text { Collector } \\
\text { (CB110) }\end{array}$ & $\mathrm{kg}$ & $3.19 \mathrm{E}+01$ & 1.2 \\
\hline & $\begin{array}{l}\text { Water ( } 20 \% \text { recy- } \\
\text { cled from pond) }\end{array}$ & $\mathrm{kL}$ & $1.08 \mathrm{E}+02$ & 1.7 \\
\hline Water treatment & Lime & $\mathrm{kg}$ & $2.40 \mathrm{E}+02$ & 2.0 \\
\hline Transportation & $\begin{array}{c}\text { Chemicals from } \\
\text { Kwinana }\end{array}$ & $\mathrm{t} \cdot \mathrm{km}$ & $1.53 \mathrm{E}+02$ & 1.2 \\
\hline $\begin{array}{l}\text { Electricity } \\
\text { generation }\end{array}$ & $\begin{array}{l}\text { LPG for electricity } \\
\text { generators }\end{array}$ & $\mathrm{kg}$ & $2.48 \mathrm{E}+01$ & 1.5 \\
\hline
\end{tabular}

The mass balance diagram for the beneficiation process for the final production of 1 tonne of separated mix of REO is shown in Figure 4.

The inputs for the process are (for the final production of $22000 \mathrm{t} / \mathrm{a}$ of separated REO mix): 
1) $110000 \mathrm{t} / \mathrm{a}$ ROM ore (containing about $22 \mathrm{ML}$ of water);

2) 2640 t/a chemicals;

3) $2200 \mathrm{ML} / \mathrm{a}$ of process water outputs are:

-44000 t/a RE concentrate (plus $8800 \mathrm{~kL} / \mathrm{a}$ of water);

- 2200 ML/a waste water;

$-176000 \mathrm{t} / \mathrm{a}$ of beneficiation fine residues (contained in waste water).

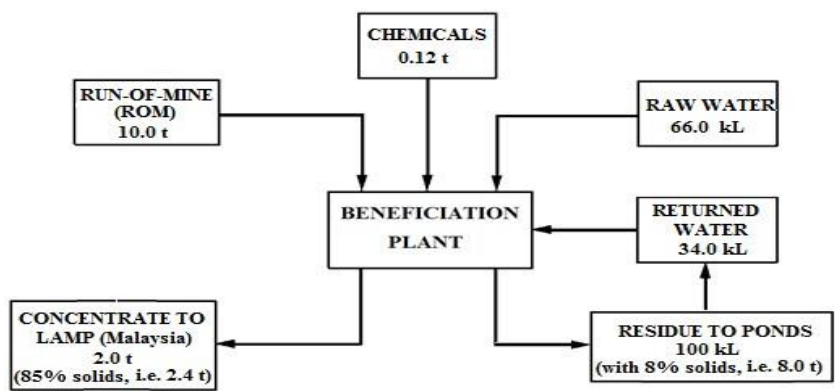

Figure 4. Mass balance diagram for beneficiation plant for the final production of 1 tonne of separated REO

REO concentrate produced by beneficiation plant contained some radioactive materials: about $0.115 \%$ of thorium and $0.005 \%$ of uranium. Solid residue from beneficiation plant contained approximately $0.059 \%$ of thorium and $0.00125 \%$ of uranium. This very low level radioactive waste after water evaporation from residue pond was returned to the mining site.

\subsection{Water and power supply}

Operation of the beneficiation plant required water in following processes:

1) potable and dust suppression uses - $880 \mathrm{ML} / \mathrm{a}$;

2) beneficiation process uses - $2200 \mathrm{ML} / \mathrm{a}$.

Approximately $30 \%$ of beneficiation process water was decanted from the residue pond (based on data reported by [11]). A small process water pond holding 12-14 days water supply was constructed near beneficiation plant (Fig. 3). Power supply was from electricity generators using LPG as a fuel [11].

\subsection{Waste management}

Both solid (dissolved in water, shown in Figure 4) and liquid wastes were generated by mining and beneficiating activities. Waste water from beneficiation plant was partly recycled supernatant water was collected and directed to the process water pond. The remaining waste water was directed to the residue pond. Water from mine dewatering and bore water were used for make-up water (the beneficiation residue pond contains approximately $8 \%$ solids, which is different from standard mining tails [11]). The water balance for Mt. Weld mine and beneficiation plant is shown in Figure 5.

Sewage which produced on site was treated by package treatment system with waste water directed to the residue pond. Miscellaneous wastes such as sanitary waste from facilities and reagent containers that could not be returned to the suppliers were disposed on the site in a sanitary landfill.

\section{Transportation REO concentrate from beneficiation plan to LAMP}

REO concentrate produced at the beneficiation plant was packed, containing about $40 \%$ of REO (wet weight).

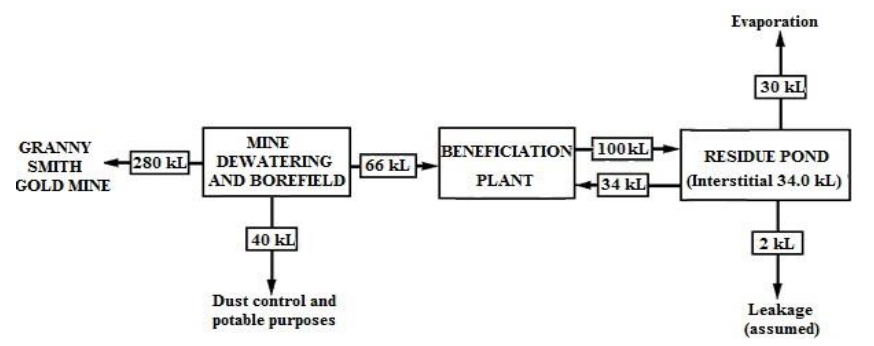

Figure 5. Water balance for Mt. Weld site (for the final production of 1 tonne separated REO)

The concentrate shipped from Mt. Weld to Kuantan contained approximately $0.13-0.16 \%$ thorium and $0.0021-$ $0.0029 \%$ uranium [25]. The sum of the activity concentrations of Th-232 and U-238 was therefore about 6 Becquerel per gram $(\mathrm{Bq} / \mathrm{g})$. Since the sum of the activity concentrations of Th-232 and U-238 was less than $10 \mathrm{~Bq} / \mathrm{g}$, the concentrate fell outside the scope of the IAEA Regulations for the Safe Transport of Radioactive Material and could therefore be transported as non-radioactive material.

The rare earth concentrate was packed into plastic bags of 1 or $2 \mathrm{t}$ capacity at the Mt. Weld site and the bags were in turn be loaded into $20 \mathrm{t}$ sea-land containers (SLCs). The containers were transported by road to Fremantle port (approximately $1000 \mathrm{~km}$ away from the beneficiation plant) for shipment to Singapore and from there by a smaller vessel to Kuantan port. Up to this point the rare earth concentrate was transported as normal nonradioactive material, in accordance with international regulations. From Kuantan port, the containers were transported by road to the facility at Gebeng Industrial Park $15 \mathrm{~km}$ away. Under Malaysian regulations, the final transport leg of the rare earth concentrate must be transported as other radioactive materials. The transport was carried out by selected haulers and trained truck drivers [25].

The transportation for REO concentrate from beneficiation plant to LAMP is shown in Figure 6.

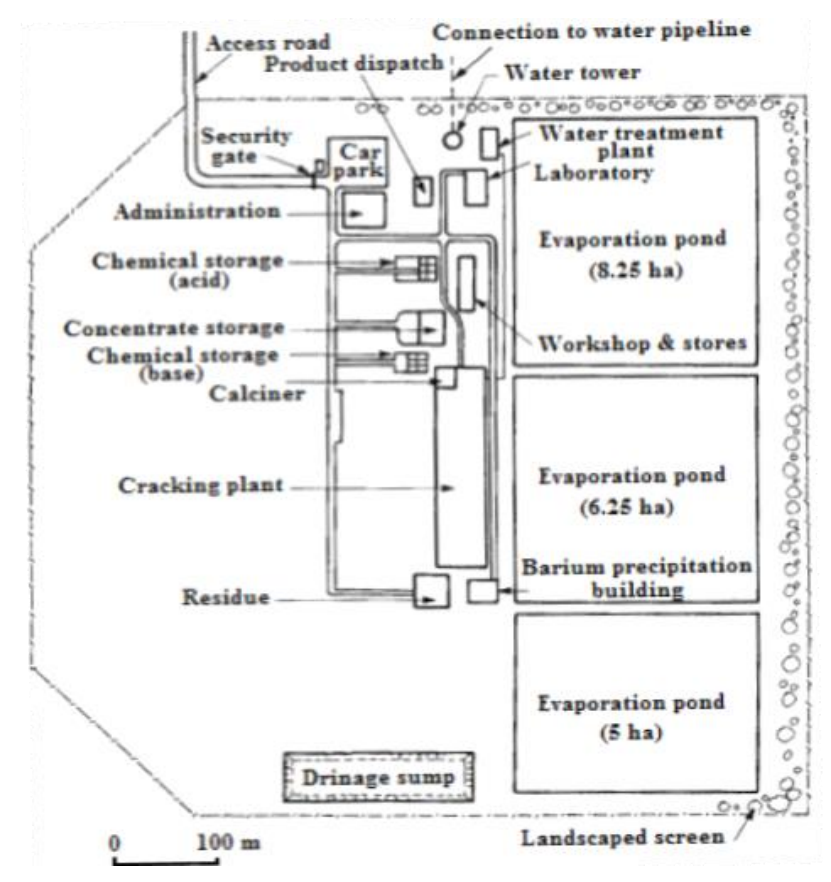

Figure 6. Conceptual site plan of Lynas Advanced Material Plant (LAMP) [11] 
Based on chemical composition of REO contained minerals from Mt. Weld and taking into account of $90 \%$ of REO extraction from the concentrate, the production of $1 \mathrm{t}$ of separated REO mix required transportation of $2.78 \mathrm{t}$ of the concentrate. Inputs required for concentrate transportation per $1 \mathrm{t}$ of produced separated REO mix are presented in Table 8 .

Table 8. Inputs for REO concentrate transportation to LAMP per Itonne of the separated mix of REO production

\begin{tabular}{lcccc}
\hline \multicolumn{1}{c}{ Process } & Amount & Units & $\begin{array}{c}\text { Per 1 tone } \\
\text { of mix REO }\end{array}$ & $\sigma^{2} \operatorname{logn}$ \\
\hline $\begin{array}{l}\text { Transportation } \\
\text { by trucks (30 t) } \\
\text { to Fremantle }\end{array}$ & 5 & $\mathrm{t} \cdot \mathrm{km}$ & $2.78 \mathrm{E}+03$ & 1.1 \\
$\begin{array}{l}\text { Transportation } \\
\text { (by ship) to Kuantan }\end{array}$ & 10 & $\mathrm{t} \cdot \mathrm{km}$ & $1.11 \mathrm{E}+04$ & 1.1 \\
$\begin{array}{l}\text { Transportation } \\
\text { by trucks (30 t) to LAMP }\end{array}$ & 600 & $\mathrm{t} \cdot \mathrm{km}$ & $2.78 \mathrm{E}+01$ & 1.1 \\
$\begin{array}{l}\text { Packaging (steel drums) } \\
\text { Packaging (plastic bags) }\end{array}$ & 10 & $\mathrm{~kg}$ & $1.01 \mathrm{E}+02$ & 1.2 \\
& 40 & $\mathrm{~kg}$ & $4.84 \mathrm{E}+01$ & 1.2 \\
\hline
\end{tabular}

\section{REO extraction and separation}

\subsection{Plant location and layout}

The LAMP for the secondary processing of REO concentrate to produce separated mix of REO is situated in Gebeng Industrial Estate (Malaysia) and occupied about 100 ha of land. LAMP had the state-of-the-art technology integrated into plant design and was the largest RE processing in the world [26]. A conceptual site plan for LAMP is shown if Figure 6. This plant processing REO concentrate shipped from Australia, which contained monazite mineral. A simplified sequence of LAMP operations is presented in Figure 7.

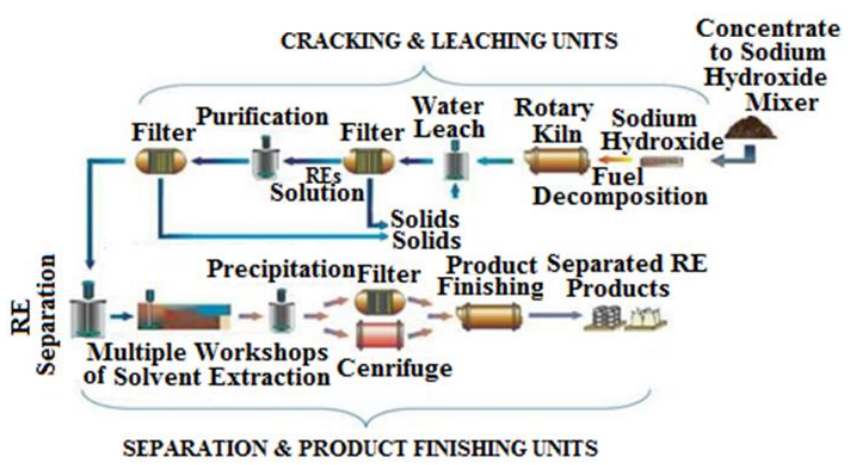

Figure 7. A simplified sequence of REO separation at LAMP[16]

The monazite mineral is a source of mostly light REE from lanthanum group [27]. As mentioned before the mineral monazite from Mt. Weld contained some radioactive elements - thorium and uranium $(\sim 0.28 \% \mathrm{Th} ; \sim 0.06 \% \mathrm{U})$, and it also contained substantial amount of phosphorus (more than $25 \%$ of phosphorus oxides) [11], which must be removed during extraction process. Although there were several other industrial processes are used to extract REO from monazite, the hydrometallurgical process, based on alkaline leaching, was currently commercially used as it had some advantages. The most important advantages were simultaneous removal of phosphorus and regeneration of alkali. Phosphorus was a useful by-product for building materials (sodium phosphate).

As the production of building materials by-product was still under development. Therefore this was not considered in this study and phosphorus sulphate was treated as waste. Regeneration of alkali was considered as important in this study, as it reduced the environmental impact from extraction of REE, as well as the cost of production.

The hydrometallurgical process of the concentrate at LAMP consisted of the following stages:

- pre-leaching;

- calcination;

- caustic conversion (with caustic regeneration/concentration);

- drying;

- hydrochloric acid leaching;

- separation of light and medium REE by solvent extraction;

- cerium oxidation and precipitation from light REE;

- lanthanum/cerium (La/Ce) separation from neodymium/ praseodymium $(\mathrm{Nd} / \mathrm{Pr})$ mix using solvent extraction process;

- lanthanum separation using solvent extraction process;

- precipitation of all obtained RE chlorides and sulphates by using oxalic acid;

- filter and calcine to produce final are earth oxides and carbonates.

A flow-sheet incorporating stages of REO extraction and separation with input and output flows and waste steams for the production of functional unit of the study (1 tonne of separated mix of REO) is provided in Figure 8.

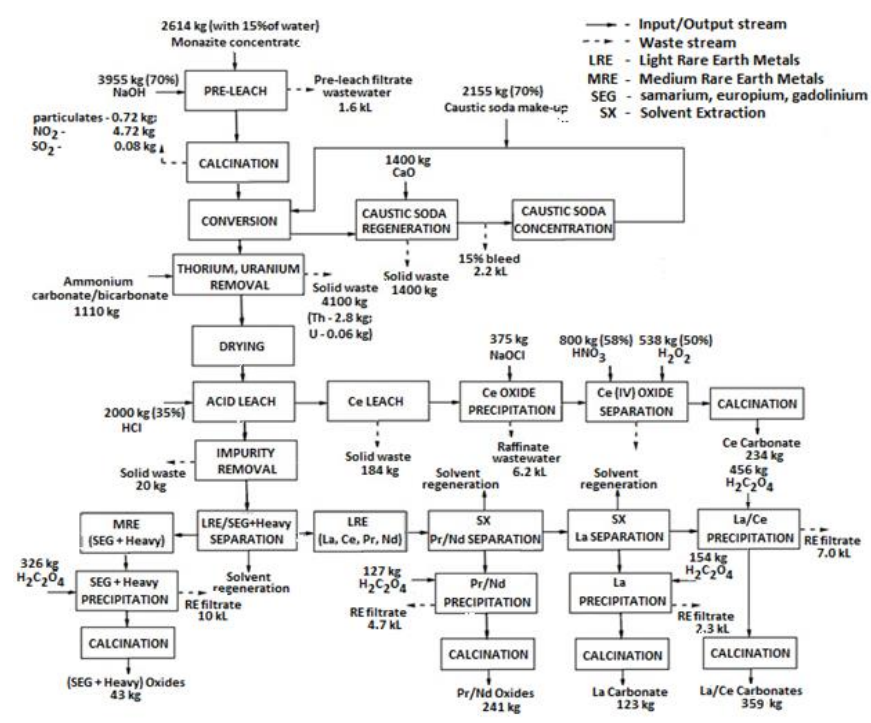

Figure 8. Flowsheet diagram for separation and extraction of REO by LAMP (input, output and waste steams quantities are shown for the production of 1 tonne of separated mix of REO) [11], [26]

As the REO extraction and separation processes produced substantial amount of effluents and wastes, LAMP included the following waste treatment processes: air effluent treatment, wastewater treatment, solid residue disposal including low radioactive wastes. The processes of extracting and separating of REO by LAMP for the purpose of this study were divided on four major stages:

1) cracking and leaching;

2) solvent extraction;

3) product finishing;

4) effluents treatment and waste disposal.

\subsection{Stage 1: cracking and leaching}

Sodium hydroxide solution at temperature of $140^{\circ} \mathrm{C}$ was used for alkali leaching. The REO concentrate was mixed with concentrated sodium hydroxide and cracked at a high temperature in a rotary kiln to convert REO to RE hydroxides. Water was then added in the leaching stage and im- 
purities in the form of iron phospho-gypsum are removed. This was followed by selective separation of thorium and uranium from REO by another autoclave leaching of hydroxide cake (obtained from previous process) with ammonium carbonate/bicarbonate $\left(\left(\mathrm{NH}_{4}\right)_{2} \mathrm{CO}_{3} /\left(\mathrm{NH}_{4}\right) \mathrm{HCO}_{3}\right)$ solution. This method was based on the dissolution of thorium and uranium hydroxides in ammonium carbonate solution with formation of thorium ammonium and uranyl carbonate complexes, while RE hydroxides formed sparingly soluble double carbonates. The process of decomposition of these ammonium complexes was done by passing steam through carbonate solutions producing thorium concentrate, which contained thorium in the form of hydrated thorium carbonate and uranium in the form of hydrated oxides [28]. The ammonia evolved from decomposition of carbonate solutions was recycled for the regeneration of ammonium carbonate [29].

\subsection{Stage 2: solvent extraction (SX)}

The hydroxide cake obtained from the previous stage was leached with hydrochloric acid at the $80^{\circ} \mathrm{C}$ and diluted with water. Then the cerium separation process was carried out by using bleaching powder of sodium hypochlorite. After removal of oxidised cerium (IV) together with rest of thorium and uranium with the selective precipitation, the REE cake was produced (free of radioactive elements). The leachate of trivalent REE was concentrated by evaporation.

The separation of REE was conducted using the solution extraction (SX) processes. SX employed two liquid phases and was carried out in liquid-liquid counter current "Solvent Extraction Trains". SX was divided into two areas, each area had three sections:

1) Upstream Solvent Extraction to separate light RE (lanthanum, cerium, praseodymium, neodymium - LCPN) and heavier RE - medium RE (samarium, europium, gadolinium SEG) plus heavy RE (HRE):

a) LCPN extraction;

b) SEG + HRE extraction;

c) HRE solution iron removal process.

2) Downstream Solvent Extraction:

a) didymium extraction ( $\mathrm{Pr} / \mathrm{Nd}$ separation);

b) lanthanum extraction (La);

c) didymium purification (didymium, samarium separation and return samarium to the SEG product).

Bis 2-ethylhexyl phosphonic acid mono-2-ethylhexyl ester (PC88-A) diluted in kerosene was used for separation process of light RE and SEG. The RE elements acid feeds of pH 1.0 and twelve contacts of SX were usually used. The precipitation of RE was carried out to remove foreign elements, which co-extracted and redissolved the precipitate in the suitable aqueous acid volume for re-extraction as before. All light $\mathrm{RE}$ found in the second extraction raffinate were returned to the primary extraction circuit. This was a multi = step process: for the light and SEG + HRE separation process, six extraction cascades, seven scrubbing cascades and six stripping cascades were used.

A similar SX process was used for recovery individual RE from the mixture of light RE. The RE were separated using extractant in hydrochloric acid. The separation of individual $\mathrm{RE}$ was a difficult process. For the separation of light fraction and SEG + HRE the multi-step process involved 22 steps: eight for extraction; eight for scrubbing; six for stripping [30].
The process of solvent extraction set-up comprising mentioned cycles is shown in Figure 7.

Additional ammonium hydroxide is used to control $\mathrm{pH}$ at each step of the SX process. The organic effluent from the process is recycled in the circuit without any additional treatment. As a result, of the SX process the REO yield at about $90 \%$ was obtained [30].

\subsection{Stage 3: product finishing}

In the final stage of the production process, the separated mix of REO was produced as carbonates, hydroxides or oxalates. At this stage some of the hydroxides were calcined to the respective oxides (didymium and SEG). The LAMP produced the following finished products: Lanthanum-Cerium Carbonate $\left(\mathrm{La}_{2}\left(\mathrm{CO}_{3}\right)_{3} / \mathrm{Ce}_{2}\left(\mathrm{CO}_{3}\right)_{3}\right)$, Lanthanum Carbonate $\left(\mathrm{La}_{2}\left(\mathrm{CO}_{3}\right)_{3}\right.$; Cerium Carbonate $\left(\mathrm{Ce}\left(\mathrm{CO}_{3}\right)_{2}\right)$, Praseodymium/Neodymium (Didymium) Oxide $\left(\mathrm{Pr}_{6} \mathrm{O}_{11} / \mathrm{Nd}_{2} \mathrm{O}_{3}\right)$, Samarium Europium Gadolinium (SEG) + Heavy Rare Earths (HRE) Carbonate $\left(\mathrm{Me}_{2}\left(\mathrm{CO}_{3}\right)_{3}\right)$ [26].

\subsection{Stage 4: effluents treatment}

At this stage gases from the cracking and leaching areas were treated to remove different sulphur oxides (dioxide, trioxide) and produced a solid synthetic gypsum by-product. An iron phospo-gypsum product was generated from the water leaching process. Water from the plant was treated by the acid neutralisation system. A solid magnesium-rich gypsum by-product was generated from this process. All solid waste materials from the plant are to be safely disposed in a dedicated approved area.

The major inputs for the LAMP production of separated REO from monazite concentrate are presented in Table 9 (presented in Table 9 amount were related for the production of 1 tonne of separated mix of RE oxides/carbonates).

\section{Results and discussion}

Based on the above assumptions, input/output streams, and waste streams, the LCI was modelled using SimaPro 7.3 [13] to calculate environmental impacts of the "cradle-to-gate" production of separated mix of rare earth oxides/carbonates. The LCI model consists of 25 unit processes and 5 SimaPro assemblies. Table 10 presents the results of contribution from each stage of the production processes of REO to the mean (m) impact for each characterisation factor under consideration in this study, its coefficient of variation (cv) and minimum and maximum value with $95 \%$ of confidence.

Results are obtained for the production of 1 tone of separated mix REO the relative to production of 11000-22000 tons of REO by LAMP per annum. Six characterisation factors relevant to the major environmental impacts "from cradle-to-gate" life cycle have been reported for the chosen functional unit:

1) Global warming (GWP) in $\mathrm{kg}$ of $\mathrm{CO}_{2}$ equivalent - " $\mathrm{CO}_{2} \mathrm{~kg}$ ";

2) cumulative energy demand (CED) in mega joules - "MJ";

3) water usage (WU) in cubic meters -" $\mathrm{m}^{3}$ ";

4) solid waste generation ( $\mathrm{SW}$ ) in kilograms -"kg";

$5)$ radiation generation factors $(\mathrm{R})$ based on damage factor units for "Ecoindicator 99" converted into hours of disability per life - "hours/life");

6) overall human health $(\mathrm{HH})$ impact in hours of disability per life - "hours/life" [13]. 
Table 9. Major inputs for the production of separated REO at LAMP per 1 t of REO production

\begin{tabular}{|c|c|c|c|c|}
\hline Process & Reagent & Units & $\begin{array}{l}\text { Per } 1 \mathrm{t} \text { of } \\
\text { mix REO }\end{array}$ & $\sigma^{2} \log n$ \\
\hline \multirow{3}{*}{ Pre-leaching } & $\begin{array}{c}\text { Hydrochloric } \\
\text { acid }(\mathrm{HCl}, 0.5 \mathrm{M})\end{array}$ & $\mathrm{kg}$ & $8.70 \mathrm{E}+01$ & 1.2 \\
\hline & $\begin{array}{l}\text { Calcium oxide } \\
(\mathrm{CaO}, 80 \%)\end{array}$ & $\mathrm{kg}$ & $1.02 \mathrm{E}+03$ & 1.2 \\
\hline & Process water & $\mathrm{kL}$ & $3.00 \mathrm{E}+00$ & 1.3 \\
\hline \multirow{2}{*}{$\begin{array}{c}\text { Monazite } \\
\text { decomposition }\end{array}$} & $\begin{array}{l}\text { Sodium hydro- } \\
\text { xide }(\mathrm{NaOH}, 70 \%)\end{array}$ & $\mathrm{kg}$ & $1.02 \mathrm{E}+03$ & 1.4 \\
\hline & Process water & $\mathrm{kL}$ & $1.27 \mathrm{E}+01$ & 1.3 \\
\hline \multirow{4}{*}{$\begin{array}{c}\text { Solvent } \\
\text { extraction } \\
\text { (LRE and MRE } \\
\text { separation) }\end{array}$} & $\begin{array}{l}\text { Hydrochloric } \\
\text { acid (HCl, } 6 \mathrm{M})\end{array}$ & $\mathrm{kg}$ & $1.61 \mathrm{E}+03$ & 1.3 \\
\hline & $\begin{array}{l}\text { Ammonium hyd- } \\
\text { roxide }\left(\mathrm{NH}_{4} \mathrm{OH}\right)\end{array}$ & $\mathrm{kg}$ & $6.77 \mathrm{E}+02$ & 1.3 \\
\hline & $\begin{array}{l}\text { Organic solvent } \\
(\mathrm{PC} 88 \mathrm{~A}, 1 \mathrm{M})\end{array}$ & $\mathrm{kg}$ & $1.57 \mathrm{E}+00$ & 1.3 \\
\hline & Water & $\mathrm{kL}$ & $1.07 \mathrm{E}+02$ & 1.3 \\
\hline \multirow{4}{*}{$\begin{array}{l}\text { Cerium } \\
\text { separation }\end{array}$} & $\begin{array}{c}\text { Nitric acid } \\
\left(\mathrm{HNO}_{3}, 68 \%\right)\end{array}$ & $\mathrm{kg}$ & $8.10 \mathrm{E}+02$ & 1.3 \\
\hline & $\begin{array}{c}\text { Hydrogen pero- } \\
\text { xide }\left(\mathrm{H}_{2} \mathrm{O}_{2}, 50 \%\right)\end{array}$ & $\mathrm{kg}$ & $2.49 \mathrm{E}+02$ & 1.3 \\
\hline & $\begin{array}{l}\text { Organic solvent } \\
\text { (PC88A, } 1 \mathrm{M})\end{array}$ & $\mathrm{kg}$ & $5.15 \mathrm{E}+01$ & 1.3 \\
\hline & Water & $\mathrm{kL}$ & $1.64 \mathrm{E}+02$ & 1.3 \\
\hline \multirow{4}{*}{$\begin{array}{l}\text { Lanthanum } \\
\text { separation }\end{array}$} & $\begin{array}{l}\text { Hydrochloric } \\
\text { acid }(\mathrm{HCl}, 6 \mathrm{M})\end{array}$ & $\mathrm{kg}$ & $8.16 \mathrm{E}+02$ & 1.3 \\
\hline & $\begin{array}{l}\text { Sodium hydro- } \\
\text { xide }(\mathrm{NaOH}, 4 \mathrm{M})\end{array}$ & $\mathrm{kg}$ & $7.52 \mathrm{E}+01$ & 1.3 \\
\hline & $\begin{array}{l}\text { Organic solvent } \\
\text { (PC88A, } 1 \mathrm{M})\end{array}$ & $\mathrm{kg}$ & $3.70 \mathrm{E}+01$ & 1.3 \\
\hline & Water & $\mathrm{kL}$ & $2.51 \mathrm{E}+02$ & 1.3 \\
\hline $\begin{array}{c}\text { Cerium } \\
\text { Carbonate } \\
\text { Production }\end{array}$ & $\begin{array}{c}\text { Sodium } \\
\text { hypochloride } \\
(\mathrm{NaOCl}, 10 \%)\end{array}$ & $\mathrm{kg}$ & $5.75 \mathrm{E}+02$ & 1.3 \\
\hline $\begin{array}{l}\text { Lanthanum } \\
\text { Carbonate } \\
\text { Production }\end{array}$ & $\begin{array}{c}\text { Oxalic acid } \\
\left(\mathrm{H}_{2} \mathrm{C}_{2} \mathrm{O}_{4}, 30 \%\right)\end{array}$ & $\mathrm{kg}$ & $1.57 \mathrm{E}+02$ & 1.3 \\
\hline $\begin{array}{l}\text { Didyum Oxide } \\
\text { Production } \\
\end{array}$ & $\begin{array}{c}\text { Oxalic acid } \\
\left(\mathrm{H}_{2} \mathrm{C}_{2} \mathrm{O}_{4}, 30 \%\right)\end{array}$ & $\mathrm{kg}$ & $1.02 \mathrm{E}+02$ & 1.3 \\
\hline $\begin{array}{c}\text { SEG + Heavy } \\
\text { Oxides } \\
\text { Production } \\
\end{array}$ & $\begin{array}{c}\text { Oxalic acid } \\
\left(\mathrm{H}_{2} \mathrm{C}_{2} \mathrm{O}_{4}, 30 \%\right)\end{array}$ & $\mathrm{kg}$ & $3.16 \mathrm{E}+02$ & 1.3 \\
\hline $\begin{array}{c}\text { Overall } \\
\text { Electricity } \\
\text { Consumption }\end{array}$ & $\begin{array}{c}\text { Malaysia } \\
\text { Electricity mix } \\
\text { (from grid) }\end{array}$ & $\mathrm{kWh}$ & $3.49 \mathrm{E}+03$ & 1.4 \\
\hline $\begin{array}{l}\text { Overall Heat } \\
\text { Consumption }\end{array}$ & $\begin{array}{l}\text { Heat from burn- } \\
\text { ing natural gas }\end{array}$ & MJ & $4.78 \mathrm{E}+04$ & 1.6 \\
\hline
\end{tabular}

The results also estimate uncertainty from input data of unit processes. For direct inputs, uncertainty range was estimated using the pedigree matrix model specified for the Ecoinventv.2. database [31], [32]. The model assumes inventory data fit a log-normal distribution. Based on the pedigree matrix approach, parameters of log-normal probability density functions (PDF) of the each input data have been estimated according to six factors: reliability, completeness, temporal correlation, geographic correlation, technological correlation, and sample size. The uncertainty is reported as the square of the geometric standard distribution, $\sigma^{2}$ (uncertainty estimates are presented in the last column of input tables). Uncertainties for all background data was perpetuated from LCA software SimaPro 7.3 [13]. Using estimated uncertainty Monte Carlo simulations have been conducted to calculate uncertainties of obtained results. The fixed numbers of 1000 runs have been performed for each unit process. The average part of data that contained uncertainty parameters was about $65 \%$.

The SimaPro model for LCI the production route under consideration has been designed using various life cycle parameters, such as REO concentration within ore $(10 \%)$; production capacity of LAMP (22000 tonnes of separated REO per annum); life time of production process (10 years); etc. Those parameters can be easily adjusted in case of changes in the future without change the overall model.

SimaPro model allow compare contribution to overall environmental impact from different phases of separated REO production from mining to REO extraction and separation by LAMP (Table 10). The results presented in Table 10 show that stage of extraction and separation of REO performed by LAMP produces the biggest environmental impact.

Results for three major characterization factors of environmental impacts (namely - GWP, CED, HH) and their coefficients of variation for different processes of this stage are shown in Figure 9. The results presented in Figure 9 show that the biggest contributor to the environmental impact among those processes is process of separation of radioactive elements from the mix of REO concentrate. The results also show uncertainties (coefficients of variation) for each unit process obtained on basis of described above approach.

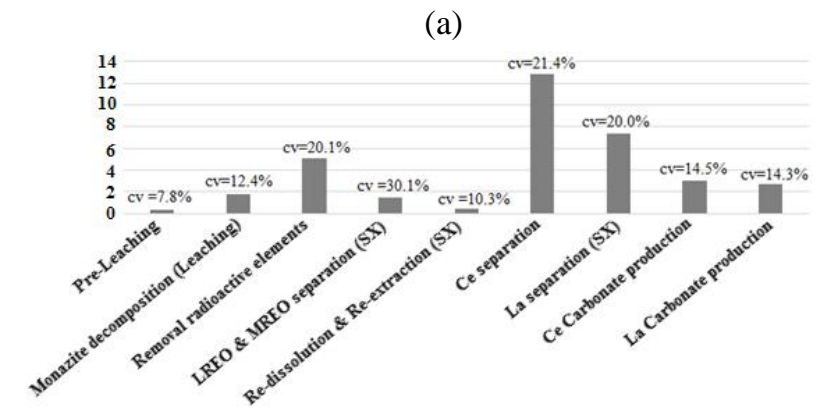

(b)

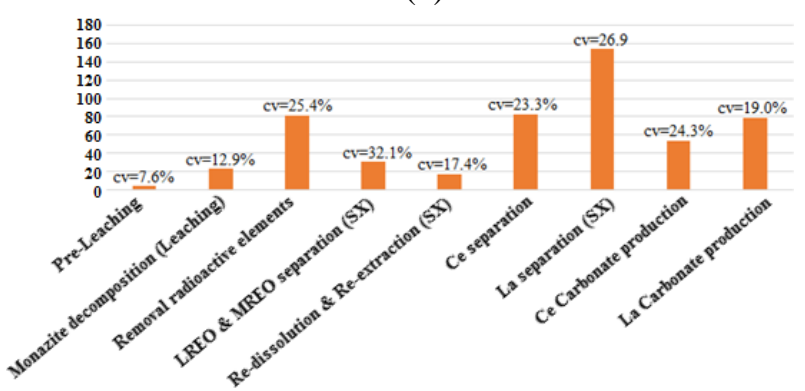

(c)

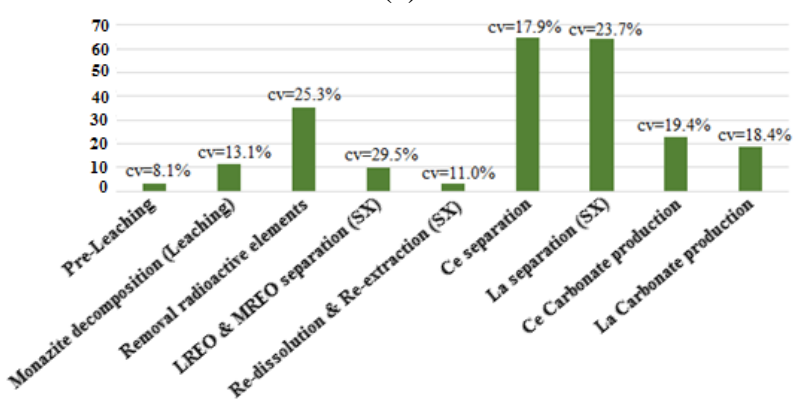

Figure 9. Average environmental impact and coefficients of variation from extraction and separation processes for production of $1 \mathrm{t}$ of separated mix of REO: (a) average $\mathrm{GWP}\left(\mathrm{CO}_{2} \mathrm{~kg}\right)$; (b) average CED (MJ); (c) average $\mathrm{HH}\left(\mathrm{hr} /\right.$ life $\left.\cdot 10^{3}\right)$ 
Table 10. Environmental impacts from the production of 1 tonne separated mix of REO

\begin{tabular}{|c|c|c|c|c|c|c|}
\hline Stage & $\begin{array}{l}\text { Global warming } \\
(\mathrm{GWP})\left(\mathrm{kg} \mathrm{CO}_{2}\right)\end{array}$ & $\begin{array}{l}\text { Primary energy } \\
(\mathrm{CED})(\mathrm{MJ})\end{array}$ & Water usage $(\mathrm{kL})$ & Solid waste $(\mathrm{t})$ & $\begin{array}{l}\text { Radiation } \\
\text { (hours/life) }\end{array}$ & $\begin{array}{c}\text { Human health } \\
\text { (HH) (hours/life) }\end{array}$ \\
\hline \multirow{4}{*}{ Mining } & $\mathrm{m}=254$ & $\mathrm{~m}=3930$ & $\mathrm{~m}=1.06$ & $\mathrm{~m}=6.9 \mathrm{E}-03$ & $\mathrm{~m}=2.64 \mathrm{E}-03$ & $m=35.9$ \\
\hline & $\mathrm{cv}=47.1 \%$ & $\mathrm{cv}=47.9 \%$ & $\mathrm{cv}=61.7 \%$ & $\mathrm{cv}=60.5 \%$ & $\mathrm{cv}=95.2 \%$ & $\mathrm{cv}=20.9 \%$ \\
\hline & $\min =97.6$ & $\min =1480$ & $\min =0.23$ & $\min =4 \mathrm{E}-03$ & $\min =2.90 \mathrm{E}-04$ & $\min =23.1$ \\
\hline & $\max =527$ & $\max =8270$ & $\max =2.62$ & $\max =0.011$ & $\max =8.56 \mathrm{E}-03$ & $\max =51.8$ \\
\hline \multirow{4}{*}{ Beneficiation } & $\mathrm{m}=237$ & $\mathrm{~m}=5230$ & $m=203$ & $\mathrm{~m}=2.1$ & $m=9.63 E-03$ & $\mathrm{~m}=3.17$ \\
\hline & $\mathrm{cv}=7.2 \%$ & $\mathrm{cv}=9.9 \%$ & $\mathrm{cv}=26.7 \%$ & $\mathrm{cv}=8.5 \%$ & $\mathrm{cv}=105 \%$ & $\mathrm{cv}=21.6 \%$ \\
\hline & $\min =207$ & $\min =4110$ & $\min =119$ & $\min =1.78$ & $\min =2.87 \mathrm{E}-03$ & $\min =2.34$ \\
\hline & $\max =274$ & $\max =6350$ & $\max =329$ & $\max =2.47$ & $\max =4.38 \mathrm{E}-02$ & $\max =4.78$ \\
\hline \multirow{4}{*}{ Transportation } & $\mathrm{m}=1220$ & $\mathrm{~m}=18600$ & $\mathrm{~m}=5.41$ & $\mathrm{~m}=0$ & $\mathrm{~m}=0.011$ & $\mathrm{~m}=14.2$ \\
\hline & $\mathrm{cv}=15.8 \%$ & $\mathrm{cv}=16.5 \%$ & $\mathrm{cv}=25.6 \%$ & $\mathrm{cv}=0$ & $\mathrm{cv}=111 \%$ & $\mathrm{cv}=14.4 \%$ \\
\hline & $\min =935$ & $\min =13900$ & $\min =3.32$ & $\min =0$ & $\min =0.0035$ & $\min =11.1$ \\
\hline & $\max =1680$ & $\max =26000$ & $\max =8.51$ & $\max =0$ & $\max =0.040$ & $\max =19.0$ \\
\hline \multirow{4}{*}{$\begin{array}{c}\text { REO extraction \& } \\
\text { separation (LAMP) }\end{array}$} & $\mathrm{m}=14900$ & $\mathrm{~m}=264000$ & $\mathrm{~m}=1310$ & $m=19.9$ & $m=0.508$ & $\mathrm{~m}=100.74$ \\
\hline & $\mathrm{cv}=8.9 \%$ & $\mathrm{cv}=11.8 \%$ & $\mathrm{cv}=8.4 \%$ & $\mathrm{cv}=18.2 \%$ & $\mathrm{cv}=85.9 \%$ & $\mathrm{cv}=10.7 \%$ \\
\hline & $\min =12700$ & $\min =210000$ & $\min =1120$ & $\min =13.9$ & $\min =0.096$ & $\min =83.4$ \\
\hline & $\max =18000$ & $\max =334000$ & $\max =1560$ & $\max =27.6$ & $\max =1.551$ & $\max =123.5$ \\
\hline \multirow{4}{*}{$\begin{array}{l}\text { Effluents } \\
\text { treatment \& auxiliary } \\
\text { processes (LAMP) }\end{array}$} & $\mathrm{m}=5310$ & $\mathrm{~m}=82300$ & $\mathrm{~m}=23.3$ & $\mathrm{~m}=0$ & $\mathrm{~m}=4.39 \mathrm{E}-02$ & $\mathrm{~m}=20.06$ \\
\hline & $\mathrm{cv}=36.4 \%$ & $\mathrm{cv}=38.4 \%$ & $\mathrm{cv}=14.6 \%$ & $\mathrm{cv}=0$ & $\mathrm{cv}=50.3 \%$ & $\mathrm{cv}=34.0 \%$ \\
\hline & $\min =2520$ & $\min =38400$ & $\min =18.8$ & $\min =0$ & $\min =1.56 \mathrm{E}-02$ & $\min =10.42$ \\
\hline & $\max =10100$ & $\max =159000$ & $\max =32.0$ & $\max =0$ & $\max =9.90 \mathrm{E}-02$ & $\max =37.05$ \\
\hline \multirow{4}{*}{ Total } & $\mathrm{m}=21900$ & $\mathrm{~m}=374000$ & $\mathrm{~m}=1540$ & $\mathrm{~m}=21.6$ & $\mathrm{~m}=0.595$ & $\mathrm{~m}=174.3$ \\
\hline & $\mathrm{cv}=10.8 \%$ & $\mathrm{cv}=12.4 \%$ & $\mathrm{cv}=8.0 \%$ & $\mathrm{cv}=16.2 \%$ & $\mathrm{cv}=94.1 \%$ & $\mathrm{cv}=8.8 \%$ \\
\hline & $\min =18200$ & $\min =302000$ & $\min =1310$ & $\min =15.7$ & $\min =0.237$ & $\min =147.2$ \\
\hline & $\max =27500$ & $\max =408000$ & $\max =1810$ & $\max =29.4$ & $\max =2.015$ & $\max =205.9$ \\
\hline
\end{tabular}

The presented results for environmental impact of "cradle-to-gate" LCA for the production of separated REO show relatively high impact of RE metals production in comparison with other bulk used metals (steel, light and heavy metals). Although these metals are mostly using as alloying elements with usually a small percentages of contribution to alloy composition, however, due to their wide spread use (for example such as lighting devices, magnetic components, lasers, etc.) their overall environmental impact could be quite high. This is can be also important, as many of those devices are treated as environmentally friendly (such as light emitted diodes (LED), wind turbines, etc.). Thus, development of technologies for recycling of these metals becomes very important tasks. Re-use of these metals not only eliminate necessary hard task of their separation, but also their mining. As their naturally occurring ores contain those metals in very low concentrations, mining and beneficiation of REO ores substantially contribute to their environmental impact. Also resource depletion of these metals is also an important issue (for example, China).

An allocation of environmental impacts for each product produced by LAMP has been done relative to:

- the contribution of the production of 1tonne of mix REO (Table 11, [12]);

- average market price for each oxide/carbonate or their mix (the assumption made is that price of produced mix (Table 11) based on the mix composition and equal half price of separated oxide);

- RE metal content within produced oxides/carbonates.

Table 11. Contribution of each product from LAMP to 1tonne of produced REO mix

\begin{tabular}{lc}
\hline Cerium Carbonate, $\mathrm{kg}$ & 234 \\
\hline Lanthanum Carbonate, $\mathrm{kg}$ & 123 \\
\hline Cerium/Lanthanum Carbonate, $\mathrm{kg}$ & 359 \\
\hline Didymium Oxide, $\mathrm{kg}$ & 241 \\
\hline SEG + Heavy Oxides, $\mathrm{kg}$ & 43 \\
\hline
\end{tabular}

The last dot point of the allocation has to be taken into account as RE usually used as metals and the metal content dictate the price of particular oxide/carbonate which can substantially different (for example, cerium oxide $\left(\mathrm{CeO}_{2}\right)$ contains $81,4 \%$ of Cerium by weight, but cerium carbonate $\left(\mathrm{Ce}\left(\mathrm{CO}_{3}\right)_{2}\right)$ contains only $53.8 \%$ of Cerium).

The allocation Formulas (1) and (2) below present the allocation of each product in overall environmental burdens from production process:

$X_{i}=\frac{P_{i} \cdot M_{i}}{\sum_{i} P_{i} \cdot M_{i}}$

where:

$P_{i}=P_{0 i} \cdot \frac{m_{C i}}{m_{O i}}$,

where:

$i-$ denotes produced separated product;

$X_{i}-\mathrm{a}$ fraction of overall burdens from production of separated REO mix allocated to the product $i$;

$P_{i}$ and $M_{i}$-calculated price for separated RE and mass contribution of each product for the production of 1 tonne of separated mix, respectively;

$P_{0 i}$ - average market price for $i$-th product;

$m_{C i}$ and $m_{O i}$ - metal content of $i$-th metal in carbonate and oxide, respectively.

The results of environmental impacts for the production of $1 \mathrm{t}$ of separated mix with contribution of each individual product to overall environmental impact are presented in Table 12.

Figures 10a-10f show the average environmental impact for each characterisation factor under consideration in this study from production of 1 tonne of each product based on described above allocation method. Table 13 presents means, as well as, minimal and maximal impacts with confidence of $95 \%$ based on uncertainty analysis conducted in this study. 
Table 12. Environmental impact from production of 1 tonne separated mix of REO allocated to each product (based on the suggested method for impact allocation

\begin{tabular}{|c|c|c|c|c|c|c|}
\hline Product & $\begin{array}{l}\text { Global warming } \\
(\mathrm{GWP})\left(\mathrm{kg} \mathrm{CO}_{2}\right)\end{array}$ & $\begin{array}{l}\text { Primary energy } \\
(\mathrm{CED})(\mathrm{MJ})\end{array}$ & Water usage (kL) & Solid waste (t) & $\begin{array}{l}\text { Radiation } \\
\text { (hours/life) }\end{array}$ & $\begin{array}{c}\text { Human health } \\
\text { (HH) (hours/life) }\end{array}$ \\
\hline Cerium Carbonate & $\begin{array}{c}\mathrm{m}=631.7 \\
\min =525.0 \\
\max =793.2\end{array}$ & $\begin{array}{c}\mathrm{m}=10787 \\
\min =8710 \\
\max =11768\end{array}$ & $\begin{array}{c}m=44.4 \\
\min =37.8 \\
\max =52.2\end{array}$ & $\begin{array}{c}\mathrm{m}=0.62 \\
\min =0.45 \\
\max =0.85\end{array}$ & $\begin{array}{c}\mathrm{m}=0.0172 \\
\min =0.0068 \\
\max =0.0581\end{array}$ & $\begin{array}{c}\mathrm{m}=5.03 \\
\min =4.25 \\
\max =5.94\end{array}$ \\
\hline Lanthanum Carbonate & $\begin{array}{c}\mathrm{m}=389.6 \\
\min =323.8 \\
\max =489.3\end{array}$ & $\begin{array}{c}m=6654 \\
\min =5373 \\
\max =7259\end{array}$ & $\begin{array}{c}\mathrm{m}=27.4 \\
\min =23.3 \\
\max =32.2\end{array}$ & $\begin{array}{c}\mathrm{m}=0.38 \\
\min =0.28 \\
\max =0.52\end{array}$ & $\begin{array}{c}\mathrm{m}=0.0105 \\
\min =0.0042 \\
\max =0.0358\end{array}$ & $\begin{array}{c}\mathrm{m}=3.10 \\
\min =2.62 \\
\max =3.66\end{array}$ \\
\hline $\mathrm{Ce} / \mathrm{La}$ Carbonate & $\begin{array}{c}\mathrm{m}=503.8 \\
\min =404.4 \\
\max =594.2\end{array}$ & $\begin{array}{c}\mathrm{m}=8450 \\
\min =6823 \\
\max =9218\end{array}$ & $\begin{array}{c}m=34.8 \\
\min =29.6 \\
\max =40.9\end{array}$ & $\begin{array}{c}\mathrm{m}=0.49 \\
\min =0.35 \\
\max =0.66\end{array}$ & $\begin{array}{c}\mathrm{m}=0.0134 \\
\min =0.0054 \\
\max =0.0455\end{array}$ & $\begin{array}{c}\mathrm{m}=3.94 \\
\min =3.33 \\
\max =4.65\end{array}$ \\
\hline Didymium Oxide & $\begin{array}{c}\mathrm{m}=17493 \\
\min =14538 \\
\max =21966\end{array}$ & $\begin{array}{c}\mathrm{m}=298740 \\
\min =241230 \\
\max =325900\end{array}$ & $\begin{array}{c}\mathrm{m}=1230 \\
\min =1046 \\
\max =1444\end{array}$ & $\begin{array}{c}\mathrm{m}=17.2 \\
\min =12.5 \\
\max =23.5\end{array}$ & $\begin{array}{c}\mathrm{m}=0.475 \\
\min =0.189 \\
\max =1.610\end{array}$ & $\begin{array}{c}\mathrm{m}=139.2 \\
\min =117.6 \\
\max =164.0\end{array}$ \\
\hline SEG + Heavy Oxides & $\begin{array}{c}\mathrm{m}=2891 \\
\min =2402 \\
\max =3630\end{array}$ & $\begin{array}{c}\mathrm{m}=49368 \\
\min =39864 \\
\max =53856\end{array}$ & $\begin{array}{c}\mathrm{m}=203.2 \\
\min =172.9 \\
\max =238.9\end{array}$ & $\begin{array}{c}\mathrm{m}=2.85 \\
\min =2.07 \\
\max =3.88\end{array}$ & $\begin{array}{c}\mathrm{m}=0.0685 \\
\min =0.0313 \\
\max =0.266\end{array}$ & $\begin{array}{c}\mathrm{m}=23.0 \\
\min =19.4 \\
\max =27.2\end{array}$ \\
\hline
\end{tabular}

Table 13. Environmental impact for the production of 1 tonne of each REO (based on the suggested method for impact allocation)

\begin{tabular}{|c|c|c|c|c|c|c|}
\hline Product & $\begin{array}{l}\text { Global warming } \\
(\mathrm{GWP})\left(\mathrm{kg} \mathrm{CO}_{2}\right)\end{array}$ & $\begin{array}{l}\text { Primary energy } \\
(\mathrm{CED})(\mathrm{MJ})\end{array}$ & Water usage (kL) & Solid waste (t) & $\begin{array}{c}\text { Radiation } \\
\text { (hours/life) }\end{array}$ & $\begin{array}{c}\text { Human health } \\
\text { (HH) (hours/life) }\end{array}$ \\
\hline \multirow{3}{*}{ Cerium Carbonate } & $m=2699$ & $m=46100$ & $\mathrm{~m}=190$ & $m=2.66$ & $\mathrm{~m}=0.073$ & $m=21.5$ \\
\hline & $\min =2243$ & $\min =37230$ & $\min =161$ & $\min =1.94$ & $\min =0.029$ & $\min =18.1$ \\
\hline & $\max =3390$ & $\max =50290$ & $\max =223$ & $\max =3.62$ & $\max =0.248$ & $\max =25.4$ \\
\hline \multirow{3}{*}{ Lanthanum Carbonate } & $\mathrm{m}=3220$ & $\mathrm{~m}=54990$ & $m=226$ & $\mathrm{~m}=3.18$ & $\mathrm{~m}=0.087$ & $\mathrm{~m}=25.6$ \\
\hline & $\min =2676$ & $\min =44410$ & $\min =193$ & $\min =2.31$ & $\min =0.035$ & $\min =21.6$ \\
\hline & $\max =4044$ & $\max =59990$ & $\max =266$ & $\max =4.32$ & $\max =0.296$ & $\max =30.3$ \\
\hline \multirow[t]{2}{*}{$\mathrm{Ce} / \mathrm{La}$ Carbonate } & $\min =1145$ & $\min =19010$ & $\min =82.4$ & $\min =0.99$ & $\min =0.015$ & $\min =9.26$ \\
\hline & $\max =1731$ & $\max =26680$ & $\max =114$ & $\max =1.85$ & $\max =0.127$ & $\max =13.0$ \\
\hline \multirow{3}{*}{ Didymium Oxide } & $\mathrm{m}=71988$ & $\mathrm{~m}=1.23 \mathrm{E}+06$ & $m=5062$ & $\mathrm{~m}=71.0$ & $\mathrm{~m}=1.955$ & $m=572.9$ \\
\hline & $\min =59825$ & $\min =0.99 \mathrm{E}+06$ & $\min =4306$ & $\min =51.6$ & $\min =0.779$ & $\min =483.9$ \\
\hline & $\max =90396$ & $\max =1.34 \mathrm{E}+06$ & $\max =5950$ & $\max =96.6$ & $\max =6.624$ & $\max =676.8$ \\
\hline \multirow[b]{2}{*}{ SEG + Heavy Oxides } & $m=67228$ & $\mathrm{~m}=1.15 \mathrm{E}+6$ & $\mathrm{~m}=4727$ & $\mathrm{~m}=66.3$ & $\mathrm{~m}=1.827$ & $m=535.1$ \\
\hline & $\min =55870$ & $\min =0.93 \mathrm{E}+06$ & $\min =4021$ & $\min =48.2$ & $\min =0.727$ & $\min =451.9$ \\
\hline
\end{tabular}

(a)

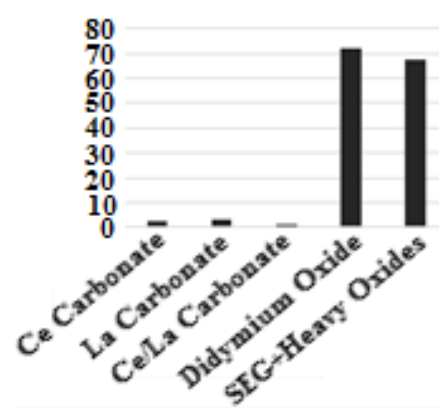

(d)

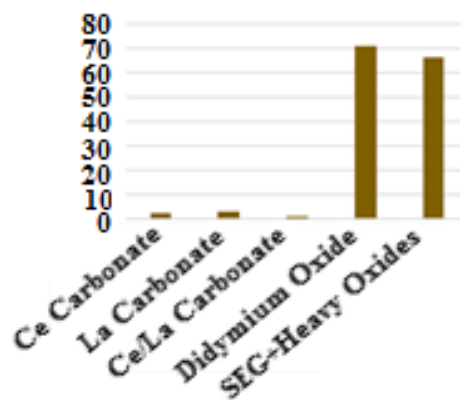

(b)

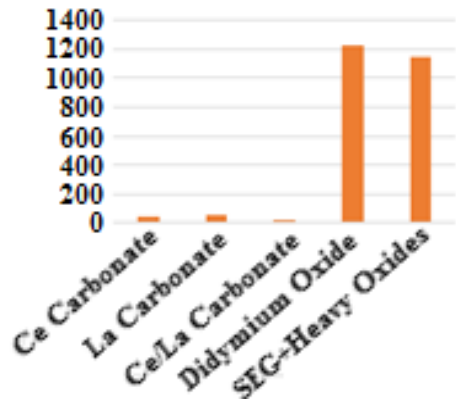

(e)

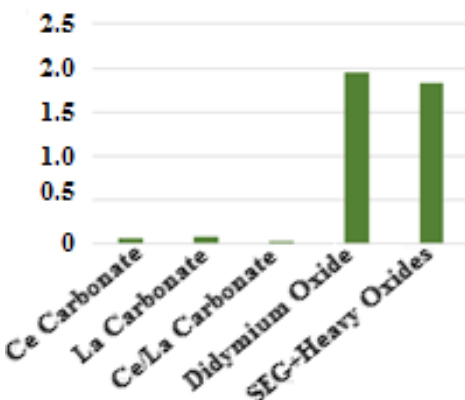

(c)

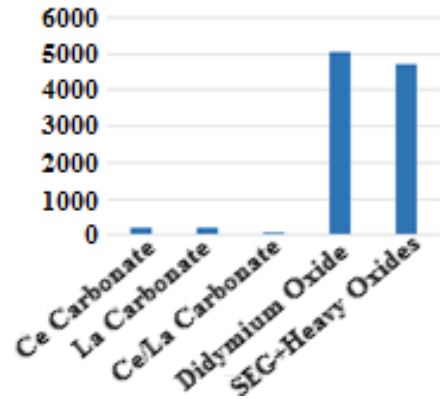

(f)

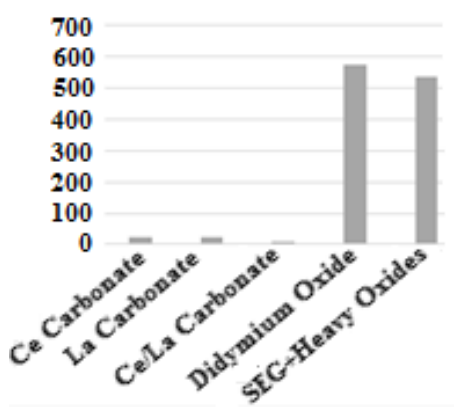

Figure 10. The average environmental impact from the production of 1 tonne of each REO (based on the suggested method for impact allocation): (a) global warming (tonne of $\mathrm{CO}_{2}$ ); (b) primary energy consumption, GJ; (c) water usage, $\mathrm{kL}$; (d) solid waste generalization, $t$; (e) radiation, hr/life; (f) human health, hr/life 
Allocation method proposed in this study for attribution environmental impact to each produced REO unlike mass based allocation and price based allocation uses combined approach. While the prices of REOs have been volatile dropping as much as 40-60\% in 2011-2012 [12], nevertheless, the comparative prices of REO are much less volatile. The sensitivity analysis shows that the REO which have high impact remain high relatively to others, however, impact of individual REEs can vary with price fluctuations. Although the perfect allocation method not exists, the used method allows more precisely calculate share of environmental burden. The presented results show that substantial part of share belongs to didymium production due to relatively high price and high composition in produced REO mix. On the other hand, contribution of SEG and heavy REO much higher than light REO lanthanum and cerium due to their substantial higher price.

Comparison two allocation methods (the method used in our study and the mass based allocation) shows that the mass based allocation is not sensitive to the comparative scarcity of the REE (per kg basis). Whereas, combining mass concentration and price of REOs, shows that impact for low concentration REEs and those that are highly priced tends to be high.

It would be interesting to compare results of environmental impacts of REO produced by Australian route of production with those reported by China production. Table 14 presents mean results for the same environmental impacts reported in different studies. Comparison of average impacts for GWP and CED for all studies reported for China production with mean results of this study shows that GWP impact is reduced by $34.2 \%$ (which is statistically significant) and CED - is reduced by about $4 \%$ (which is statistically insignificant). Although all studies use similar functional units: $1 \mathrm{~kg}$ (or 1 tonne) of separated mix of REO, however direct comparison in not quite correct as one has to keep in mind that separation process conducted in China is deeper (medium and heavy REO are also separated) and also all light REO produced in China as oxides, not carbonates, which contains more RE metals.

Table 14. Environmental impacts per $1 \mathrm{~kg}$ of separated REO produced in China and by Australian route

\begin{tabular}{lccccc}
\hline & & \multicolumn{4}{c}{ Reported impacts } \\
\cline { 3 - 6 } Category & Units & $\begin{array}{c}\text { Koltun \& } \\
\text { Tharumarajah, } \\
2014\end{array}$ & $\begin{array}{c}\text { Zaimes } \\
\text { et al. }\end{array}$ & $\begin{array}{c}\text { Vahidi } \\
\text { et al. }\end{array}$ & $\begin{array}{c}\text { This } \\
\text { study }\end{array}$ \\
\hline GWP & $\begin{array}{c}\mathrm{kg} \text { of } \\
\mathrm{CO}\end{array}$ & 42.9 & 29.1 & 28.2 & 22.0 \\
CED & $\mathrm{MJ}$ & 395.1 & 446.9 & 321.5 & 374 \\
\hline
\end{tabular}

Comparison of individual light REO, such as lanthanum and cerium, also show significant reduction in environmental impact for REO produced by Australian route with those reported for China [2]: $67 \%$ and 38\% GWP; $9 \%$ and $8 \%$ CED; $7 \%$ and $9 \%$ for water, respectively. Table 15 additionally presents comparison of some results of this study with results presented in [2] study.

\section{Conclusions}

This study has investigated in some detail the "cradle-togate" environmental impact of a rather complex route of producing REOs from Australia - starting from establishing a mine for REO extraction to production of separated mix of REOs.
Table 15. Comparison of global warming impact and primary energy consumption for some REOs produced by Australian route and in China

\begin{tabular}{lccc}
\hline \multicolumn{2}{c}{ REO Australia/China } & $\begin{array}{c}\text { GWP } \\
\text { (t CO2 eq/t) }\end{array}$ & $\begin{array}{c}\text { CED } \\
\text { (GJ/t) }\end{array}$ \\
\hline \multirow{2}{*}{ Cerium } & Australia & 3.4 & 46.7 \\
& China & 10.3 & 103 \\
\hline \multirow{2}{*}{ Lanthanum } & Australia & 4.0 & 55.5 \\
& China & 11.2 & 113 \\
\hline \multirow{2}{*}{ Didymium } & Australia & 89.4 & 1240 \\
& China & 74.0 & 746 \\
\hline \multirow{2}{*}{ Heavy } & Australia & 83.5 & 1158 \\
& China & 467 & 9329 \\
\hline
\end{tabular}

Both mass- and price-based allocation models have been employed in estimating the impact. The former is only sensitive to the extractable mass concentrations, whereas latter model proposed in this study is additionally sensitive to price. Thus, where the prices of REO vary widely, it tends to amplify the impact of highly priced rare earths that have lower concentrations. This information can be useful in focussing efforts to improve process efficiency and recycling to increase supply.

The research results suggest that the environmental impacts per unit mass of produced separated rare earth oxides and carbonates are large. These impacts are significantly increased when producing from light rare earth to medium and heavy rare earth, from approximately 3.400 tonne of $\mathrm{CO}_{2}$ eq. (global warming) and $47 \mathrm{GJ}$ of energy consumption, to 83.5 tonne of $\mathrm{CO}_{2}$ eq. and $1158 \mathrm{GJ}$ per tonne of rare earth production.

The uncertainty data analysis in this paper shows that coefficient of variance did not exceed $17 \%$ of the total of environmental impacts from REO production for the most of characterisation factors reported in the study (Table 10), with the exception of the radiation impact. Although contribution of this factor is not significant to overall impact on human health, more studies are needed to be conducted to reduce uncertainty of this characterisation factor.

An additional concern is the impact on the environment from processing waste. In particular, the large amount of tailings produced in beneficiation and extraction of concentrates from ore. Process tailings, especially those in extraction and separation, contain naturally occurring radionuclides. The release of these elements to the environment by air, wastewater, and rain leaching of tailings can have longer term health effects to humans and ecosystems of the local environment. It is known that low level radioactive waste will be stored in evaporation ponds for ten years [25], but the long term procedure of disposal of low level radioactive waste from LAMP is not known, yet. An assessment of these and other impacts from long term waste processing and disposal can be done as supplement to this study.

Taking into account of the Chinese restrictions on rare earth exports, it seems that recycling of used products containing RE would be an attractive pathway. The route to recycling can be closed-loop, meaning the recovery of the original RE alloys with minimum loss of properties for similar applications. Such direct recycling, however, has its challenges in collecting, sorting, separating components and finding suitable processes. Other open-loop recycling where a recovery of REEs in alloys or down cycling for use in other applications can also be attractive. Investigation of environmental impacts of the various routes to recycling would be a viable extension of this study. 


\section{Acknowledgements}

This study was carried out in Victoria University within Centre of Environmental Safety and Risk Engineering (CESARE). The authors would like to thank Dr. Vasily Vovozhilov, director of the CESARE for the support for this study, discussions and comments about the study, and Dr. Maria Koltun for her valuable comments during preparation of this paper.

\section{References}

[1] United States Geological Survey (USGS). (2014). Mineral commodity summaries 2014. Washington, United States: Government Printing Office.

[2] Koltun, P., \& Tharumarajah, A. (2014). Life cycle impact of Rare Earth Elements. ISRN Metallurgy, (2014), 1-10. https://doi.org/10.1155/2014/907536

[3] Sprecher, B., Xiao, Y., Walton, A., Speight, J., Harris, R., Kleijn, R., \& Kramer, G.J. (2014). Life cycle inventory of the production of rare earths and the subsequent production of $\mathrm{NdFeB}$ rare earth permanent magnets. Environmental Science \& Technology, 48(7), 3951-3958. https://doi.org/10.1021/es404596q

[4] Zaimes, G.G., Hubler, B.J., Wang, S., \& Khanna, V. (2015). Environmental life cycle perspective on rare earth oxide production. ACS Sustainable Chemistry \& Engineering, 3(2), 237-244. https://doi.org/10.1021/sc500573b

[5] Karshigina, Z., Abisheva, Z., Bochevskaya, Y., Akcil, A., Sargelova, E., Sukurov, B., \& Silachyov, I. (2018). Recovery of rare earth metals (REMs) from primary raw material: sulphatization-leachingprecipitation-extraction. Mineral Processing and Extractive Metallurgy Review, 39(5), 319-338. https://doi.org/10.1080/08827508.2018.1434778

[6] Vahidi, E., Navarro, J., \& Zhao, F. (2016). An initial life cycle assessment of rare earth oxides production from ion-adsorption clays. Resources, Conservation and Recycling, (113), 1-11. https://doi.org/10.1016/j.resconrec.2016.05.006

[7] Lynas Pty Ltd. (2013a). Lynas quarterly report for period ending 30 June 2013.

[8] Mineral prices. (2013). Retrieved from http://www.mineralprices.com/

[9] Rare Earth Elements. (2013). Geoscience Australia.

[10] Frischknecht, R. (1997). Goal and scope definition and inventory analysis. In Life cycle assessment: state of the art and research priorities. Bayreuth, Germany: Ecomed Publishers.

[11] Kinhill Engineers Pty Ltd. (1992). Mt Weld Rare Earth Project. Report.

[12] Bell, L. (2012). Rare earth and radioactive waste: a preliminary waste stream assessment of the Lynas advanced materials plant, Gebeng, Malaysia. National Toxics Network Report.

[13] Pre Consultants. (2011). LCA Software tool, SimaPro 7.3.
[14] Weidema, B.P., \& Wesnæs, M.S. (1996). Data quality management for life cycle inventories - an example of using data quality indicators. Journal of Cleaner Production, 4(3-4), 167-174. https://doi.org/10.1016/s0959-6526(96)00043-1

[15] ISO. (2006). International Standards Organization ISO 14040 Environmental management standard - Life cycle analysis - principles and framework.

[16] Lynas Pty Ltd. (2013b). Rare Earth - we touch them everyday, investor presentation, August.

[17] Google Earth 4 Software. (2013). Google.

[18] Jalal, T.S., \& Bodger, P. (2009). National Energy Policies and the electricity sector in Malaysia. $20093^{\text {rd }}$ International Conference on Energy and Environment (ICEE). https://doi.org/10.1109/iceenviron.2009.5398618

[19] Ingwersen, W. (2009). Life cycle inventory of gold mined at Yanacocha Peru. Report. Gainesville, United States: Centre for Environmental Policy, Department of Environmental Engineering Sciences, University of Florida.

[20] Hartman, H.L. (1992). SME mining engineering handbook. Littleton, United States: Society for Mining, Metallurgy and Exploration.

[21] Spielmann, M., Kägi, T., Stadler, P., \& Tietje, O. (2004). Life cycle inventories of transport services. Dübendorf, Switzerland: Swiss Centre for Life Cycle Inventories.

[22] Althaus, H., Chudacoff, M., Hischier, R., Jungbluth, N., Osses, M., \& Primas, A. (2004). Life cycle inventories of chemicals. Dübendorf, Switzerland: Swiss Centre for Life Cycle Inventories, EMPA-DU.

[23] Norgate, T., \& Haque, N. (2010). Energy and greenhouse gas impacts of mining and mineral processing operations. Journal of Cleaner Production, 18(3), 266-274. https://doi.org/10.1016/j.jclepro.2009.09.020

[24] Ecoinvent 2007, overview and methodology. (2007). Ecoinvent Report No. 1. Dübendorf, Switzerland: Swiss Centre for Life Cycle Inventories.

[25] IAEA. (2011). International review mission on the radiation safety aspect of LAMP. Report. Kuala Lumpur, Malaysia.

[26] Lynas Pty Ltd. (2012). Lynas advance materials plant.

[27] Gupta, C.K., \& Krishnamurthy, N. (1992). Extractive metallurgy of rare earths. International Materials Reviews, 37(1), 197-248. https://doi.org/10.1179/imr.1992.37.1.197

[28] Zelikman, A.N. (1963). Metallurgy of rare earth. Moscow, Russian Federation: Metallurgizdat.

[29] Sinyaver, B.V. (1966). Autoclave process in nonferrous metallurgy. Nonferrous Metals Information Moscow, 171-185.

[30] Morais, C.A., \& Ciminelli, V.S.T. (2004). Process development for the recovery of high-grade lanthanum by solvent extraction. Hydrometallurgy, 73(3-4), 237-244. https://doi.org/10.1016/j.hydromet.2003.10.008

[31] Frischknecht, R., \& Jungbluth, N. (2007). Implementation of life cycle impact methods. Data v 2.0. Dübendorf, Switzerland: Swiss Centre for Life Cycle Inventories.

[32] Weidema, B.P. (1998). Multi-user test of the data quality matrix for product life cycle inventory data. The International Journal of Life Cycle Assessment, 3(5), 259-265. https://doi.org/10.1007/bf02979832

\section{Оцінка життсвого циклу при виробництві розділеної суміші оксидів рідкоземельних металів, вироблених на основі розробленого в Австралії методу}

\section{П. Колтун, В. Клименко}

Мета. Дослідження та аналіз життєвого циклу (ЖЦ) виробництва розділеної суміші різних рідкоземельних оксидів (РзО) для визначення екологічного впливу на довкілля такого виробництва для РЗО, що видобуваються в Австралії.

Методика. Аналітичне вивчення даних з оглядів літератури, вимірювань і звітів виробників, баз даних інвентаризації життєвого циклу й обгрунтовані оцінки виробництва розділеної суміші різних РЗО. Для уточнення даних використовувався підхід на основі “родоводу” матриці та моделювання методом Монте-Карло. У дослідженні ЖЦ використовувався також метод розподілу екологічного впливу на довкілля між різними виробленими РЗО.

Результати. Отримані в дослідженні ЖЦ результати показали, що процес виробництва розділеної суміші РЗО істотно по різному впливає на довкілля в залежності від типу Р3О: для легких РЗО потенціал глобального потепління (ПГП) становить 1.7-3.9 т $\mathrm{CO}_{2}$ еквівалент на тонну вироблених Р3О; для середніх і важких РЗО цей показник значно вищий: близько 90 т $\mathrm{CO}_{2}$ еквівалент. Найбільший вплив надають оксиди празеодиму/неодиму $(\mathrm{Pr} / \mathrm{Nd})$ (близько $80 \%$ по ПГП). Екологічний вплив низько радіоактивних відходів (в разі їх належного зберігання) на здоров’я людини порівняно невеликий: приблизно $0.2 \%$.

Наукова новизна. В роботі вперше застосований метод розподілу екологічного впливу на довкілля розроблений авторами на основі вартості для виведення декількох побічних продуктів виробничого процесу. Використання методу моделювання МонтеКарло для визначення похибки отриманих результатів при дослідженні ЖЦ дозволило більш точно оцінити складові екологічного впливу на довкілля виробництва РЗО за описуваної в роботі технології їх видобутку в Австралії.

Практична значимість. Результати, отримані в дослідженні на основі запропонованої методики, дозволяють виявити екологічно “гарячі точки” у виробництві РЗО і вжити практичні заходи для зменшення негативного екологічного впливу цього виробництва.

Ключові слова: рідкоземельні метали, життєвий цикл, екологічний вплив, довкілля , метод Монте-Карло 
Оценка жизненного цикла при производстве разделенной смеси оксидов редкоземельных металлов, произведенных на основе разработанного в Австралии метода

\section{П. Колтун, В. Клименко}

Цель. Исследование и анализ жизненного цикла (ЖЦ) производства разделенной смеси различных редкоземельных оксидов (Р3О) для определения экологического влияния на окружающую среду (ОС) такого производства для РЗО, добываемых в Австралии.

Методика. Аналитическое изучение данных из обзоров литературы, измерений и отчетов производителей, баз данных инвентаризации жизненного цикла и обоснованные оценки производства разделенной смеси различных РЗО. Для уточнения данных использовался подход на основе “родословной” матрицы и моделирование методом Монте-Карло. В исследовании ЖЦ использовался также метод распределения экологического влияния на ОС между различными производимыми РЗО.

Результаты. Полученные в исследовании ЖЦ результаты показали, что процесс производства разделенной смеси РЗО производит существенно различное влияние на ОС в зависимости от типа РЗО: для легких РЗО потенциал глобального потепления (ПГП) составляет 1.7-3.9 т $\mathrm{CO}_{2}$ эквивалент на тонну произведенных РЗО; для средних и тяжелых РЗО этот показатель значительно выше: около 90 т $\mathrm{CO}_{2}$ эквивалент. Наибольшее влияние оказывают окислы празеодима/неодима ( $\mathrm{Pr} / \mathrm{Nd}$ ) (около 80\% по ПГП). Экологическое влияние от низко радиоактивных отходов (в случае их должного хранения) сравнительно невелико по влиянию на здоровье человека (примерно $0.2 \%$ ).

Научная новизна. В работе впервые применен метод распределения экологического влияния на ОС, разработанный авторами на основе стоимости для вывода нескольких побочных продуктов производственного процесса. Использование метода моделирования Монте-Карло для определения погрешности полученных результатов при исследовании ЖЦ позволило более точно оценить составляющие экологического влияния на ОС производства РЗО по описываемой в работе технологии и добываемых в Австралии.

Практическая значимость. Результаты, полученные в исследовании на основе предложенной методики, позволяют выявить экологически “горячие точки” в производстве РЗО и предпринять практические шаги для уменьшения негативного экологического влияния этого производства.

Ключевые слова: редкоземельные металлы, жизненный изкл, экологическое влияние, окружающая среда метод Монте-Карло

\section{Article info}

Received: 12 October 2019

Accepted: 17 March 2020

Available online: 18 April 2020 